\title{
オレフィン接触異性化反応における最近の進歩
}

\author{
上松 敬 禧*
}

Advance in Studies on the Catalytic Isomerization of Olefins

Takayoshi Uematsu*

\section{I. オレフィン異性化反応と触媒}

オレフィンの異性化反応の中には，骨格異性化，二重 結合移行，シスートランス異性化（幾何異性化）などが 通常よく知られており，また研究されている。これらの 異性化反応のいずれもが生起し得る最少鎖長のオレフィ ンはブテンであることから，主として，ブテン異性化反 応についての従来の研究を簡単に省みてみたい。

衆知のように, この種の反応は, 熱反応, 光化学反応 などによっても容易に進行し, 触媒反応によっても, 均 一系の酸一塩基触媒, 不均一系の金属, 金属酸化物, 特 に固体酸または固体塩基触媒など多くの触媒系が見出さ れている。ブテンがこのように各種の反応系で反応が進 行することから, 反応機構の研究, 触媒の表面物性と触 媒作用との関係などの問題において，一種のモデル反応 として，しばしば利用されている。一般に酸強度の大き な固体酸触媒の場合などを除くと, 通常の反応条件で注 骨格異性化反忘は無視できるほど少ない。同様に，二重 結合移行やシスートランス異性化に比べて, 重合や分解 反応も比較的起りにくい。しかし，オレフィンの異性化 反応は, 水素化, 脱水素反応中に, あるいは, アルコー ルの脱水, 脱八ロゲン反応などの過程にも条件によって は同時に進行することが知られ，触媒反応機構からも， 無関係ではあり得ないことが多い。ここでは，これら周 辺の反応中における異性化反応については，別の機会に 譲って，主として，各種触媒上に打ける二重結合移行反 応とシスートランス異性化反応を中心にとりあげてみた 认。特に, 触媒側の物性から得られた活性点の性質, 反 応機構, あるいは, 観測される特異的な立体選択性はど

* 千葉大学工学部合成化学科

* Department of Synthetic Chemistry, Faculty of Engineering, Chiba University
のように説明されるかなどの観点から従来の研究を省み てみることにする。

表 1 オレフィン異性化反応の触媒分類

\begin{tabular}{|c|c|}
\hline $\begin{array}{r}\text { 勾一系触媒 } \\
\text { 気相 } \\
\text { 液相 }\end{array}$ & 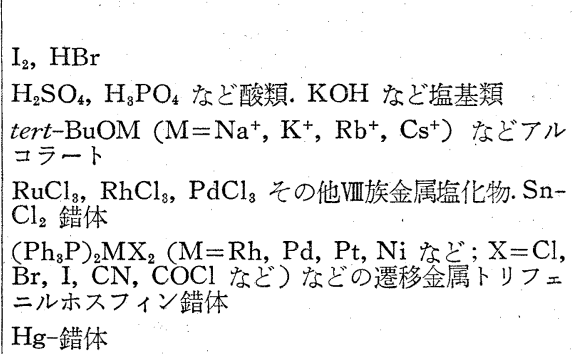 \\
\hline & 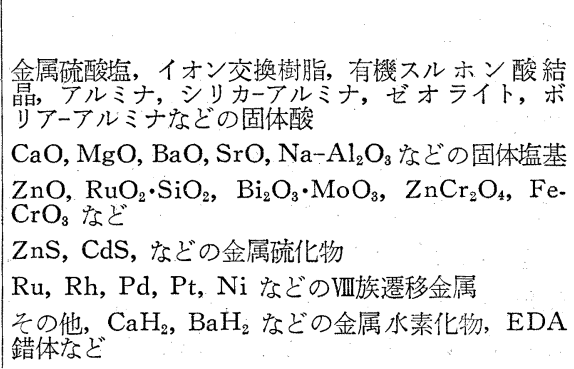 \\
\hline
\end{tabular}

表 1 は, 従来報告されている, 主としてブテン異性 化反応に関する触媒について分類したものである。八口 ゲン気体や，八ロゲン化水素はオレフィンに付加しや すいものであるが，それら付加物からの脱離によって生 成するオレフィンにすでに立体選択性がみられ，一般に は, 中間錯体がシス-型の方が安定であるとして, 説明 が試みられている。均一液相の酸-塩基に関しては, Foster らの一連の選択性に関する経験則が知られてお り, 強酸の硫酸や強塩基の水酸化カリウムがそれぞれ典 型的なカルボニウムイオン，カルバニオンを経由するも のとしてその特異な選択性の説明が試みられた。また二 塩基酸の場合には, いわゆる水素スイッチ機構が提出さ れている。VII族の金属や金属塩化物における異性化反応 
は, 多くの場合水素化反応も同時に起り, 主として 1オレフィンの異性化が多い。また塩化物に限らず，八ロ ゲンを含むVIII属金属錯体の各種配位子の立体選択性に対 する効果など新しい興味のある系である。固体酸触媒に おける異性化反応は, 従来最も多くの研究が行なわれて きた触媒系であるが, 固体酸触媒の持つ活性点がきわめ て多様性に富んだものであり, 酸点の種類, 酸強度, 酸 点の構造, その他の性質と選択性の関連という観点から の整理も試みられている。イオン交換樹脂や有機スルホ ン酸固体は, 酸の種類としてはルイス酸を含まずプロト ン酸のみであり，かつ酸強度はほぼ均一であることが期 待される系として筆者らが研究を進めたものであるが， 必らずしも予期されるよらな均一性は得られていない。 また, $p$-トルエンスルホン酸結晶は, プロトン酸型固 体酸のひとつの典型として，二重結合移行反応におい て，水素協奏機構が実験的に証明された系として知られ ている。固体塩基に関しては, カルバニオン経由の反応 機構が予想されているが, 触媒の種類も少なく, 塩基点 の性質に関してはまだ十分明らかにされたとはいえず， ルイス酸点がカチオンラジカルを生成する酸化点として 作用することと対照的に, 塩基点の一部はアニオンラジ カル生成能のある還元点として作用することが考えられ ている。固体塩基触媒の多くは, アルカリ金属やアルカ リ土類金属の酸化物であるが，均一系においては，アル カリ金属アルコラートも強塩基として考えられ，類似性 が問題となろら。金属酸化物の中には，特に強い酸-塩 基性を示さず，また触媒挙動も，典型的な酸-塩基触媒 のそれとは異なるものが少なくはない。また，金属酸化 物触媒の中には，いわゆる複合酸化物が多く，工業触媒 などでは，むしろ単一成分の酸化物は少ない。Fe-Cr 系 フェライトや, $\mathrm{Zn}$ 系スピネル, $\mathrm{Bi}-\mathrm{Mo}$ 系複合酸化物な ど，いずれもオレフィンの酸化脱水素触媒として知られ ているものであり，比族金属の場合とは逆に脱水素反応

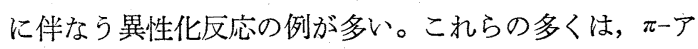
リル錯体を経由するものと考えられ，表面錯体の安定性 やコンホメーションが異性化-脱水素, あるいは, 異性 体内の選択性を決定するものと思われる。

紙数との関係もあり，今回は以上にあげた触媒系のう ちの一部について, 従来の研究の過程を述べたいと思 5 。

\section{II. 固体酸触媒によるブテン異性化}

オレフィンの異性化に関して, 熱力学から予想される 值と異なった立体選択性を最初に見出したのはVoge $\mathrm{e}^{1)}$ と思われる。その後, 酸触媒によるブテン異性化反応に

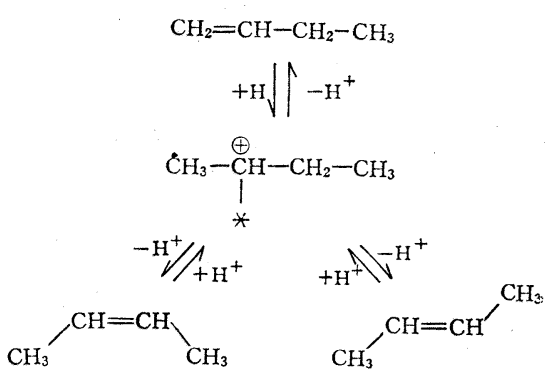

a. secーブチルカルボニウムイオン機構 (Whitmore 説)

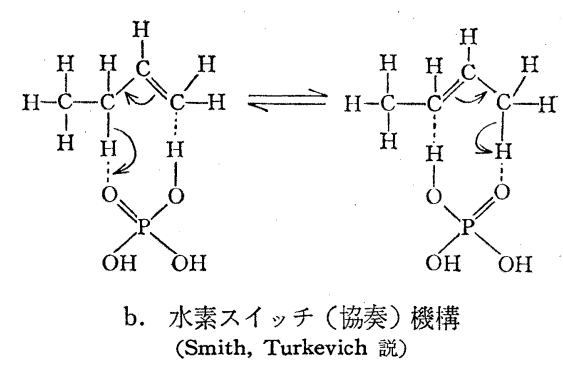

図 1 初期のオレフィン異性化反応機構

ついて，1940 年代に Whitmore ${ }^{2)}$ の説にしたがってカル ボニウムイオンで説明を試みようとした中に Thomas ${ }^{32}$

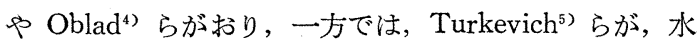
素の協奏的付加一脱離のいわゆる水素スイッチ機構を提 出した。すなわち，図１に示すように，前者では，酸触 媒からプロトンが付加して安定な sec-ブチルカルボニ ウムイオンを生成し，付加したプロトンを脱離すれば逆 反応，隣接する炭素位からプロトンとして水素が引きぬ かれれば二重結合移行が起るとした。この場合，C-C結 合は比較的自由に回転し，シスートランス 異性化は抑制 されないと考えた。

これに対して, スイッチ機構は, 二重結合移行反応の 説明には容易であるが, シスートランス異性化の進行, 特にその特異的な選択性を説明するのに無力であった。 また，この機構では，プロトン授受に関与する一組の活 性点が適当な距離をもって触媒上に存在する必要があ り，またプロトンを与える側の酸点と，受け取る側の塩 基点が協奏的に働くためには，適当な範囲での酸-塩基 強度のバランスが望ましいと考えられる。したがって， 一方の強さが極端に強ければ, 水素 付加-水素脱離ある いはこの逆過程の単なる逐次的進行になり，反応中間体 は，協奏的な，動的なものでなく，より安定なものとな る。

また，水素の授受が必らずしもプロトンとしてではな く, 触媒によっては, ハイドライドイオンや, 水素ラジ 
カルとして行なわれることも考えられる。また, 塩酸や 硝酸では異性化が起りにくく, 硫酸やリン酸で反応しや すい理由として，スイッチ機構での説明も行なわれてい る。

Lucchesi $^{6)}$ らは, Turkevich らの説では，1-ブテンか らの異性化の際のシス/トランス選択性の高い原因を説 明できぬため, プロトン $\pi$ 電子の相互作用による錯体 を反応中間体と考え，しかも，トランス-2-ブテンへの 異性化は，シス-2-ブテンを経由する逐次反応，

$1-\mathrm{C}_{4} \mathrm{H}_{8} \longleftrightarrow$ cis $-2-\mathrm{C}_{4} \mathrm{H}_{8} \rightleftarrows$ trans $-2-\mathrm{C}_{4} \mathrm{H}_{8} \cdots \cdots[1]$ であることを主張した。しかし，多くの固体酸触媒にお いて，出発物質をいずれのブテンにかえても，反応初期 から必らず他の二つのブテンを生成すること，塩基性物 質の吸着や，反応生成物による被毒によって活性が極端 に変化しても，選択性はあまり変動しないことなどから 固体酸触媒では，三つのブテン間の相互変換反応である とみられている。また次に述べるように，反応中間体に 同一の共通な中間体を想定する Haag, Pines ${ }^{7)} ら$ 説が 認められている。

また，彼等は，アルミナ上でのブテン異性化反応が 〔2〕で表わされるものとし，

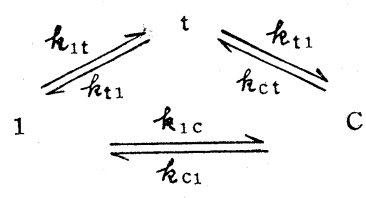

$$
k_{1 \mathrm{t}} \cdot k_{\mathrm{tc}} \cdot k_{\mathrm{c} 1} / k_{1 \mathrm{c}} \cdot k_{\mathrm{t} 1} \cdot k_{\mathrm{ct}}=1
$$

が成立することから, 初期選択性と, 三つの平衡定数を 用い，形式的な相対反応速度定数を求めた。なおこの方

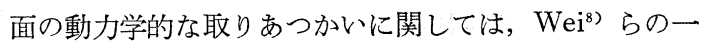
連の研究がある。また Haag らの考えた共通中間体は, やはり sec-ブチルカルボニウムイオンであるが, 二重 結合移行のシス選択性が強いことの説明として，気相へ の脱離に際して, Lucchesi と同様な $\pi$ 電子-プロトン錯 体を経由するものとし， $\mathrm{Ag}^{+}$一オレフィン錯体のシス錯 体がより安定であること, ブテン異性体の塩基性の相異 などから脱離過程で選択性が決定されるものとした（図 2) $。$

一方 Foster ${ }^{9)}$ らは固体酸のみならず均一系を含めて, 酸一塩基触媒一般についての選 択性との関係を論じた。 すなわち，選択性因子 (Selectivity factor) として，

$\mathrm{S}_{\mathrm{b}}^{\mathrm{a}}=\left[(\mathrm{a} / \mathrm{b}) /\left(\mathrm{a}_{\mathrm{e}} / \mathrm{b}_{\mathrm{e}}\right)-1\right] /\left[(\mathrm{a} / \mathrm{b}) /\left(\mathrm{a}_{\mathrm{e}} / \mathrm{b}_{\mathrm{e}}\right)+1\right] \cdots \cdots[4]$ なる值を定義した。これによると， $\mathrm{S}_{\mathrm{b}}^{\mathrm{a}}=1\left(\mathrm{~S}_{\mathrm{b}}^{\mathrm{a}}=-1\right)$ は異性体 $\mathrm{a}$ のみ生成し, b は全く生成しない場合であり, $\mathrm{S}_{\mathrm{b}}^{\mathrm{a}}=0$ は， $\mathrm{a}$ と $\mathrm{b}$ が平衡比で生成する場合である。なお

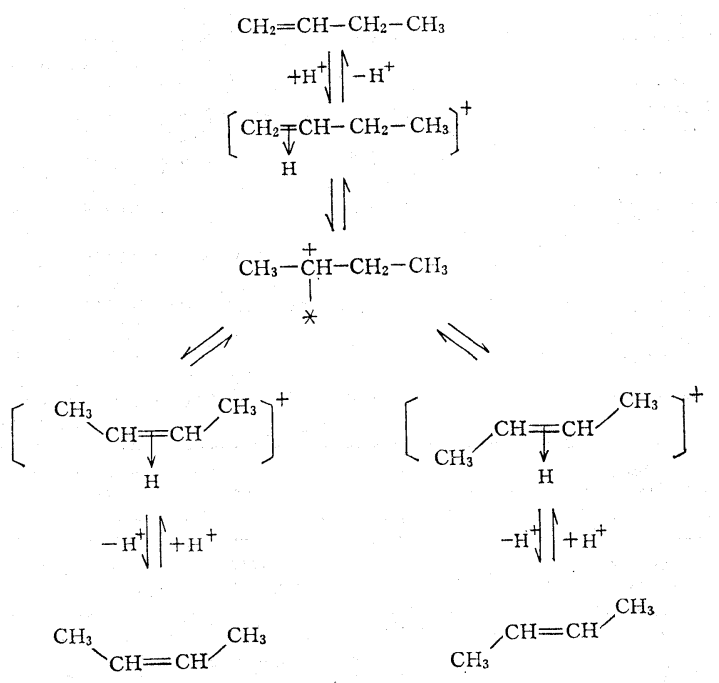

図 2 sec-ブチルカルボニウムイオンを共通中間 体とし $\pi$-錯体経由の機構 (Haag, Pines 説)

表 2 各種触媒と選択性因子との関係 選択性因子 (Foster による)

\begin{tabular}{|c|c|c|c|c|}
\hline 触 & $\begin{array}{c}\text { 反応温度 } \\
\left({ }^{\circ} \mathrm{C}\right)\end{array}$ & $\begin{array}{c}1-フ ゚ テ ン ~ \\
S_{t}^{c}\end{array}$ & $\begin{array}{l}\text { シス-2-ブ } \\
\text { テン } \mathrm{S}_{\mathrm{t}}^{1}\end{array}$ & $\begin{array}{l}\text { トランス-2- } \\
\text { ブテン } \mathrm{S}_{\mathrm{c}}^{1}\end{array}$ \\
\hline $\mathrm{KOH}$ & 320 & $\begin{array}{r}0.89 \sim \\
1.00\end{array}$ & 1.00 & 1.00 \\
\hline $\mathrm{NaOH}$ & 400 & 0.55 & $0.99 \sim 1.00$ & 0.42 \\
\hline $\mathrm{LiOH}$ & 440 & 0.45 & 0.94 & 0.87 \\
\hline $\mathrm{CaO}$ & 200 & 0.74 & - & 1.00 \\
\hline Vicor & 100 & 0.53 & 0.11 & 0.48 \\
\hline 活性炭 & 250 & 0.37 & 0.20 & -0.14 \\
\hline $\mathrm{ZnO}$ & 550 & 0.37 & -0.18 & - \\
\hline 活性白土 & 40 & 0.55 & 0.92 & 0.65 \\
\hline $\begin{array}{l}\text { シリカアルミナ } \\
\text { (11\%アルミナ) }\end{array}$ & 35 & 0.68 & 0.89 & - \\
\hline アルミナ & 300 & 0.39 & $\begin{array}{r}-0.97 \sim \\
-1.00\end{array}$ & $\begin{array}{r}-0.99 \sim \\
-1.00\end{array}$ \\
\hline $\mathrm{H}_{3} \mathrm{PO}_{4}$ & 150 & 0.39 & 0.18 & -0.5 \\
\hline $\mathrm{H}_{2} \mathrm{SO}_{4}$ & 30 & 0.50 & -1.00 & -1.00 \\
\hline $\mathrm{Ni}+\mathrm{H}_{2}$ & 300 & 0.70 & 0.14 & $0.87 \sim 1.00$ \\
\hline $\mathrm{Ag}$ & 375 & 0.13 & 0.82 & 1.00 \\
\hline
\end{tabular}

$a_{e}, b_{e}$ は各異性体の平衡濃度を示す。結果を 表 2 に示 す。たとえば, 典型的な酸触媒である硫酸と, 同じく塩 基性触媒である水酸化カリウムを比較すると, 酸触媒で はシスートランス異性化はいきやすいが，二重結合移行 反応は促進されず，1-ブテンからの異性化はシス選択性 が強くないのに対して, 塩基触媒ではその逆であること がわかる。しかし，このような現象的分類だけでは，触 媒の状態や，固体触媒に予想される不均一性，たとえ ば，ルイス酸, プロトン酸などの酸種, 酸塩基の強度, その他の相異，立体化学的な構造の問題などの因子の影 響が考慮されていない。また，反応経路，反応機構，反 
応条件，転化率など無視された因子が大きいにもかかわ らず大胆な展望をする場合有用である。彼はこの結果を 酸触媒一カルボニウムイオン機構, 塩基触媒一カルバニオ ン機構としてまとめた。塩基触媒において, シスー選択 性が強い理由として，カルバニオンの部分電荷のひろが りが，カルボニウムイオンと異なり C-C 間の自由回転 を抑制するためとした。類似の現象としてスチレン重合 の場合, 酸触媒ではアタクチックポリマーが, 塩基触 媒では, イソタクチックポリマーができることを考えて いる。後述するように, 酸種や酸強度と選択性との間に は密接な相関関係が見出されてきており, 反応機構と関 連してかなり詳細な研究が今日では進んでいる。

分光学的な研究は, 触媒の動作状態とも関連して重要 であるが，以上述べた段階では，カルボニウムイオンの 存在も， $\pi$ 電子一プロトン錯体も類推の域を出ていない。 固体酸触媒のオレフィンの吸着状態をしらべた研究とし ては, Peri, Leftin, および Little らのものが知られて いる。Peri ${ }^{10)}$ は，高温排気したアルミナ上に 1-ブテン を導入すると, シス-2-ブテン類似の IR スペクトルが 得られることを指摘した。このことは, 二重結合を保持 した表面錯体の存在を示している。異性化反応速度が,

$\mathrm{D}-\mathrm{H}$ 交換速度より速く, 高温排気により $\mathrm{OH}$ 基が減少 するにもかかわらず異性化活性が上昇することからこの 表面錯体は，相隣接したアルミニウムに $\pi$ 電子が配位し たものを予想した（図 3)。また，シスートランスの選択 性は, この種の錯体のうち, シス型錯体がトランス型錯 体よりも安定であることによるとしている。(もっとも, Little ${ }^{11)}$ は, Peri の解勫に対して，2-ブテンとは考えら れるが，シスートランスの区別は難かしいとしている。）

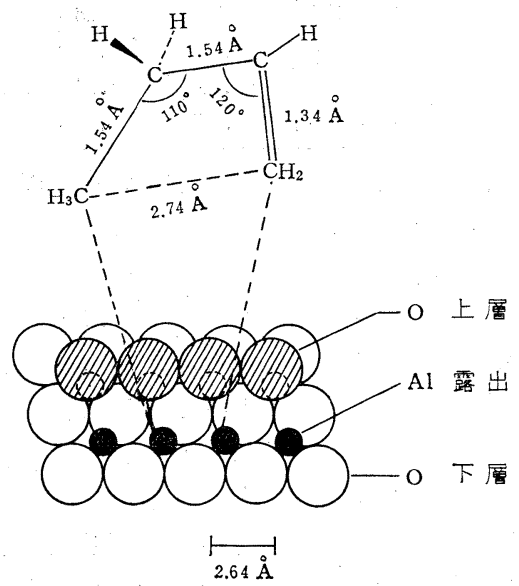

図 3 アルミナ上に吸着したシス-錯体の配置
またシリカーアルミナ上でも 1-ブテン吸着が，二重結合 性を残していることを指摘した ${ }^{10 b)}$ 。金属触媒上のオレ フィン吸着が水素付加したアルキル基, あるいは二個の 吸着点をとる会合型吸着であることと対照的であること に注目すべきである。

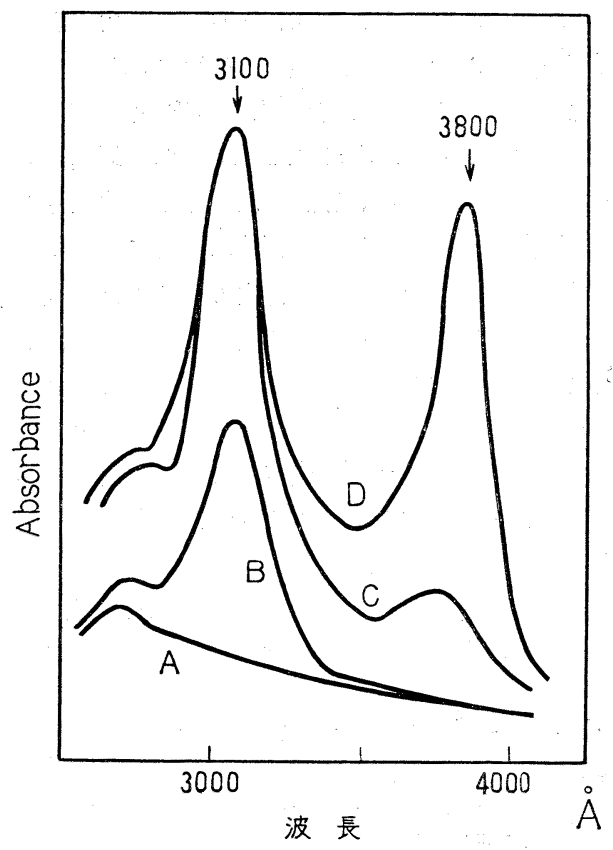

図 4 吸着ブテンの紫外スペクトル

1ーブテン道入 シリカーアルミナ（12\% アルミナ） $A:$ 導入前

B, C, D : 経時変化

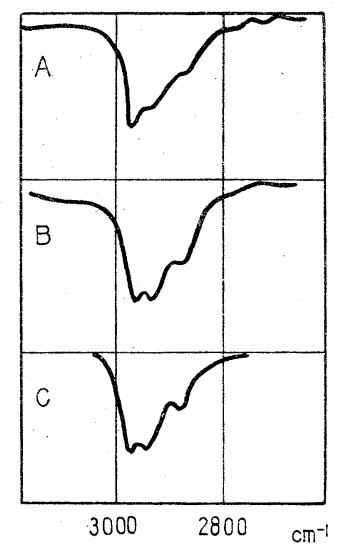

図 5 シリカーアルミナ上のブテニル カルボニウムイオンの同定 (IR)

$\mathrm{A}: 2$ :クロロプタン- $\mathrm{SbCl}_{3}\left(80^{\circ} \mathrm{C}\right)$ sec-ブチル $\mathrm{B}: 3$ ークロロ-1-ブテン- $\mathrm{SbCl}_{3}\left(80^{\circ} \mathrm{C}\right)$ sec-ブテニル

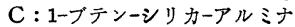


シリカーアルミナ上の 1-ブテンをUV スペクトルで観 測した Leftin ら ${ }^{12}$ の研究がある。図 4 に示す。脱気前 処理を十分に行なったシリカーアルミナでは，300〜310 $\mathrm{m} \mu$ に単一の吸収ピークが現われ, $250^{\circ} \mathrm{C}$ まで昇温して も強度は減少せずむしろ強まった。さらに温度を上げる と $380 \mathrm{~m} \mu$ 付近にも吸収が現われてくるが，彼は前者を 触媒上のルイス酸点がハイドライドイオンを引きぬき， ブテニルカルボニウムイオンが生成したものと考えた。 この根拠として, 図 5 に示すような 3-クロロ-1-ブテ ンから生成したブテニルカルボニウムイオンのスペクト ルとの類似性を挙げている ${ }^{12 \mathrm{~b})}$ 。また， $380 \mathrm{~m} \mu$ に生じ た吸収はコーク形成のためであるとしている。

$$
\mathrm{CH}_{2}=\mathrm{CH}-\mathrm{CH}_{2}-\mathrm{CH}_{3}+\sqcup
$$

$$
\rightleftarrows \mathrm{CH}_{2}=\mathrm{CH}=\mathrm{CH}-\mathrm{CH}_{3}+\mathrm{H}^{\ominus}
$$

しはルイス酸を示す。Leftin の描く反応機構は 図 6 に示す。すなわち，1-ブテンには，ゴーシュ型とトラン ス型とが存在し, 気相では自由回転により統計的には 2 対 1 の割合で平衡化している。吸着によって生成する sec-ブテニルカルボニウムイオンには, シス型（アンチ 型）とトランス型 (シン型) の 2 種が考光られ，ゴーシ ユ型 1-ブテンからはシス型表面錯体を，トランス型の 1ーブテンからはトランス型表面錯体を形成する。アルケ ニルカルボニウムイオンの上記 2 種の安定性は大きく異 なり，また両者間の $\mathrm{C}_{2} \sim \mathrm{C}_{3}$ 軸自由回転による転換はエ ネルギー障壁が 大きいこと，したがってシス-2-ブテン とトランス-2-ブテン間の異性化反応は, 反応中間体を 直接通してではなく，むしろ気相の1ーブテンを仲介し (gauche)<smiles>C=CC(C)CC</smiles>

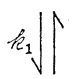<smiles>CCCC</smiles>

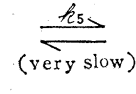

$k_{3} \sqrt{\mid}$

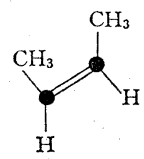

シスー2-ブテン

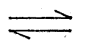

$$
\text { 1ーブテン }
$$

(trans)

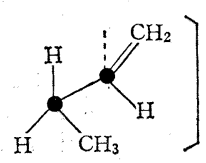

$h_{2} \mid$

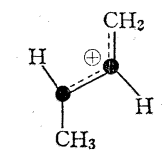

龙 $\mid \sqrt{\mid}$

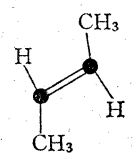

トランスー2-プテン
图 6 sec-プテニルカルボニウムイオン機構 (Leftin 説)

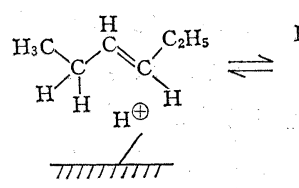

(1)

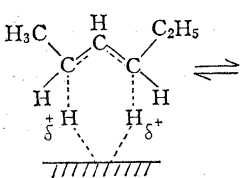

(2)

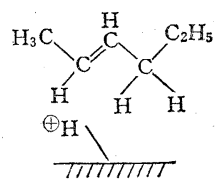

(3) a）トランスー3ーへキセンの水素スイッチ機構による二重結合移行<smiles>CCCC</smiles><smiles>C/C=C\C</smiles>

b）シスー3-ヘキセンの場合。メチル基の反溌があり，遷移状態 (2) がブテンに比べてとりにくく不安定。

へキセン異性化の水素スイッチ機構による説明 (Brouwer説)

図 1

て行われ，1-ブテン異性化のシス-選択性が強いのは， 吸着過程, 二つのブテニルカルボニウムイオンの安定 性, およびそれらの脱離過程で決定されるとした。

固体酸触媒上の活性点は必らずしも一種類と考光る必 要はなく,また二重結合移行反応とシスートランス異性 化を同じ反応機構で説明する必然性むない。Brouwer ${ }^{132}$ らは Haag 以来の安定なブチルカルボニウムイオン中 間体説の難点として, 選択性の触媒依存性が大きいこ と，オレフィンの相異による生成オレフィン中のシス/ トランス比の変化が大きいことをあげ，さらに，表面錯 体のコンホメーション変化の十分速い系でも選択性は大 きいことから，これらの安定性の差だけでは説明しきれ ないことを指摘している。そこで、シリカーアルミナ触 媒上の 3-ヘキセンの異性化において, 生成する 2-へキ セン中のシス/トランス比が小さいことを図 7 に示す ようにスイッチ機構を考えれば説明しやすいとして, シ スートランス異性化は sec-ブチルカルボニウムイオン機 構, 二重結合移行はスイッチ機構で進行し, 両者が共存 する複合反応であると主張した。

Hall ら ${ }^{14)}$ は, 固体酸触媒上の水素の挙動を重水素を トレーサーとしてしらべる一連の研究を行なってアルミ ナ，シリカーアルミナ，ゼオライトなどの活性点の性質 がかなり異っていることを明らかにしている。重水で処 理したシリカからは異性化にともならDのとり込みがあ るのに対して，アルミナでは比較的少ないことから，ア ルミナ上の活性点は, Peri と同様, 図 3 に示した $\mathrm{O}^{2-}$ イオン上にシス型錯体としてお扔いかぶさって安定化 し、より高いシス/トランス比を与えると想像した。ま たブチルカルボニウムイオンは図8 に示すように, $\mathrm{C}_{1}$, $\mathrm{C}_{2}, \mathrm{C}_{3}$ および $\mathrm{C}_{2}$ 上の $\mathrm{H}_{\mathrm{d}}$ で平面構造を取り, 触媒面 に平行に吸着する。 $\mathrm{C}_{3}$ 上の $\mathrm{H}_{\mathrm{a}}$ が脱離すればシス-2-ブ 
テンの生成, $\mathrm{H}_{\mathrm{b}}$ が脱離すればトランス-2-ブテンが生 成するとし， $\pi$ 電子一プロトン錯体は考えていない。ま た，スイッチ機構を仮定して錯体の遷移状態に図 $8 \mathrm{~b} の$ ようなコンホメーションを考え，2つのゴーシュ型のら ち，表面錯体として有効なのは図に示した1つであるか らシス/トランスは 1 に近いことを指摘したが，シリカー アルミナ上での可能性を示唆するのに止まった。

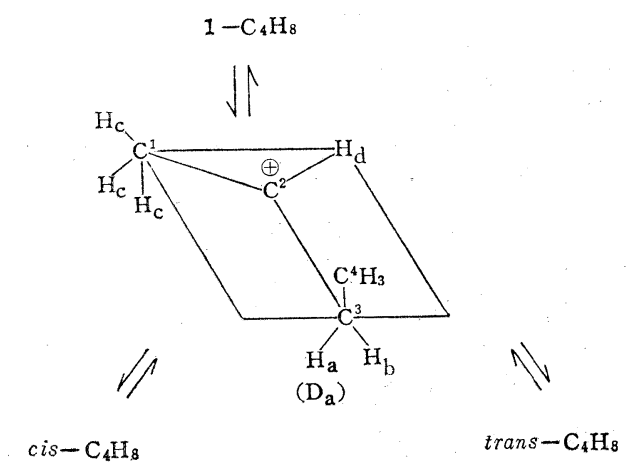

a. sec-ブチルカルボニウムイオン機構 (Hall)

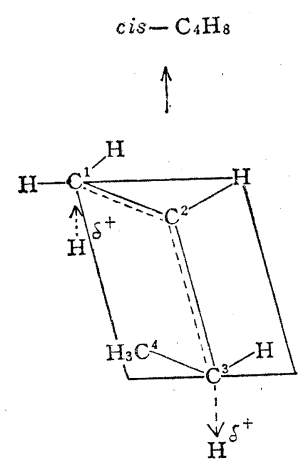

Gauche 型遷移状態

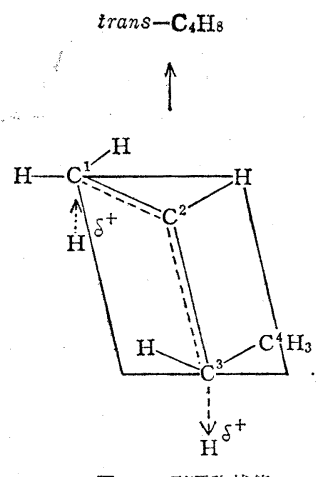

Trans 型遷移状態 b. 水素スイッチ機構 (Hall)

図 8 ブテン異性化反応中間体

\section{III. 酸点の性格と選択性}

前章で述べてきた固体酸は主としてアルミナ, または シリカーアルミナであり，したがってピリジン吸着15)や， アンモニア吸着 ${ }^{16)}$ の IR スペクトルから明らかにされた ように，プロトン酸とルイス酸の少なくとも二種類の酸 点の存在が知られている。Hall らがブテン異性化の機 構をシリカーアルミナ上で区別したのは，アルミナ上で は酸点の大部分がルイス酸点であることからも必然の結 果であ万ら。筆者は17), シリカーアルミナ系触媒で 1-ブ テン異性化反応の選択性がプロトン酸量の多いものほど トランス側に; ルイス酸量の多いものほどシス-2-ブテ
ンへの選択性が強いことを見出した（図 9)。これは金 属置換X型ゼオライトなどにあてはまるようであり, カ ドミウム置換ゼオライトに水を添加するか, 炭素質の蓄 積でプロトン酸点が形成されるとシス選択性が減少し, 酸強度の減少では説明できないことを示した。これは, ブテニルカルボニウムイオンの方が，ブチルカルボニウ ムイオンよりもシス選択性が強いことを示唆しているも のと理解できる。

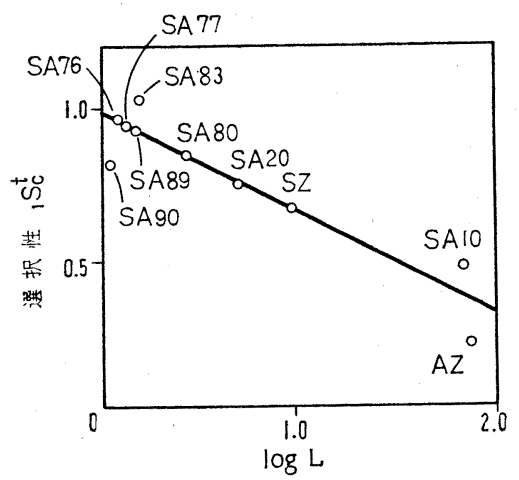

図 9 シリカーフルミナ系固体酸のルイス酸量と選択性

$\mathrm{L}: ル 1$ ス酸量 $(\mathrm{meq} / \mathrm{g}) \times 10^{3}$ ${ }_{1} \mathrm{~S}_{\mathrm{c}}^{\mathrm{t}}: 1$-ブテン異性化の選択性 trans/cis $\mathrm{SA}:$ シリカーアルミナ 数字はンリカ\% $\mathrm{SZ}:$ ンリカージルコニア $\mathrm{AZ}:$ アルミナージルコニア

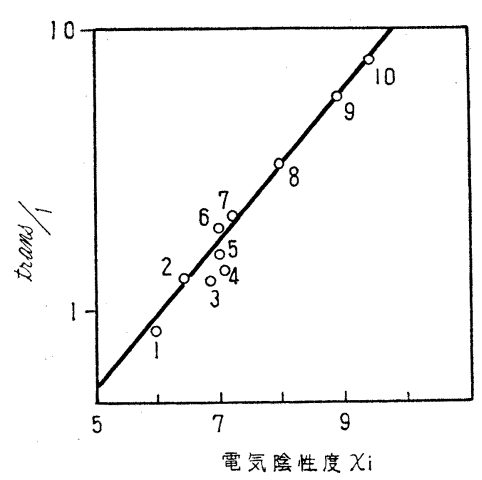

図 10 金属イオンの電気陰性度とシス-2-ブテン 異性化選択性 (金属硫酸塭)
1. $\mathrm{Mg}^{2+}$
6. $\mathrm{Zn}^{2+}$
2. $\mathrm{Mn}^{2+}$
7. $\mathrm{Cu}^{2+}$
3. $\mathrm{Co}^{2+}$
8. $\mathrm{Sc}^{3+}$
4. $\mathrm{Ni}^{2+}$
9. $\mathrm{Al}^{3+}$
5. $\mathrm{Cd}^{2+}$
10. $\mathrm{Fe}^{3+}$

またプロトン酸型固体酸の選択性に関しては，金属硫 酸塩を用いた御園生らの研究がある。図 10 亿示すよう に金属イオンの酸強度の尺度として, 電気陰性度をとる と選択性との間に直線関係が得られた ${ }^{18 a)}$ 。この触媒で は, 前処理条件などからみて, 金属イオンに配位した $\mathrm{H}_{2} \mathrm{O}$ の分極によって生ずるプロトン酸の酸強度が現われてい 
るむのと考えられる。反応中間体としては図 $8 \mathrm{a}$ に示し た Hall らの sec-ブチルカルボニウムイオンを考え, また，シリカーアルミナで提出したエネルギープロフィ ルを強酸の代表としての硫酸了ルミニウムと弱酸の代表 としての硫酸マグネシウムについて求めている ${ }^{18 b)}$ 。 なわち，条件式〔3]が成立し，共通の中間体を経由する 反応であると考元, 出発物質をかえた時の選択性の温度 係数から他の二つの異性体一の過程の活性化エネルギー の差を算出し, 原料ブテンの消失速度の活性化エネルギ 一を考慮して描いたものである（図 11）。硫酸マグネシ ウムでは, 中間体のカルボニウムイオンは不安定で, 遷 移状態を越えて各異性体へと進む活性化エネルギーの差 は小さく, したがって，2-ブテン/1-ブテン，およびシ ス/トランスの選択性はいずれも比較的 1 亿近い。一方

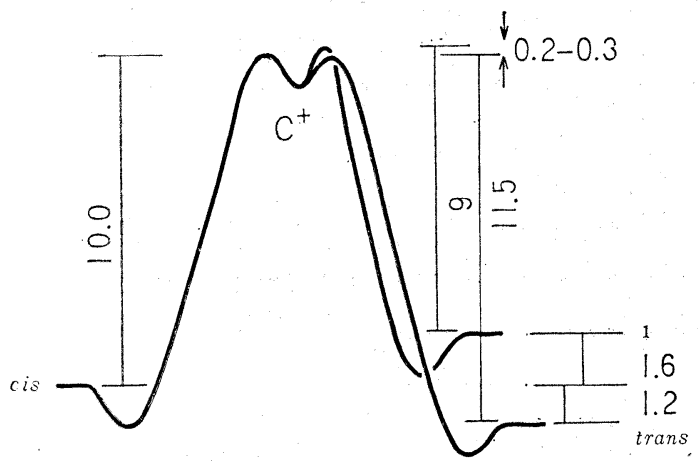

A 弱酸 (シリカ担体付硫酸アルミナ)

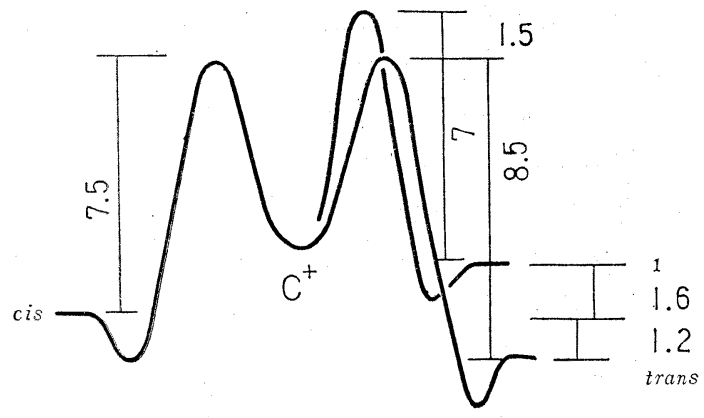

B 強酸 (シリカ担体付硫酸マグネシウム)

図 11 固体酸触媒の酸強度とブテン異性化のエネルギ ープロフィル (sec-ブチルカルボニウムイオン)

硫酸アルミニウムでは, カルボニウムイオンは安定化し てしまい，また活性化エネルギ一差は大きく，選択性 (2-ブテン/1-ブテン) は大きくなる。また弱酸では，プ ロトン付加が脱離に比べて遅くなり, 反応がより協奏的 になるとしている。

\section{IV． 同位元素標識法による反応機構の研究}

触媒反応機構を解明する場合, 同位元素を標識として トレーサー実験をすることは，きわめて有力な情報を与 えてくれる。たとえば，(1) 異性化にともなら触媒上で の水素の授受から表面錯体の構造, 分子間または分子内 の水素の移行のしかた, 触媒上の水素の解離・非解離の 問題，（2）重水素化オレフィン，重水，重水素ガスなど を気相に共存，あるいは前処理による水素源の性質の推 定 (3) 同位体効果の解析による律速段階の推定や, ${ }^{14} \mathrm{C}$ とDを単独または併用しての複合反応経路の解析と単一 過程の速度の測定，(4) 生成物中の同位元素の数や位置 の決定から反応機構の推定など, 他の方法では得難、情 報が得られる。一般に触媒上では， $n$-ブテンの異性化 に関する反応スキームとして次の四つの可能性がある。

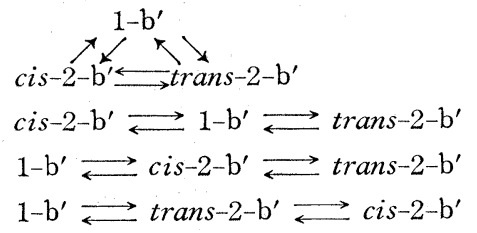

田中は ${ }^{19)}$ ，ここで塩化ロジウム触媒上の反応に ${ }^{14} \mathrm{C}$ を

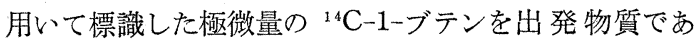
るシスー2-ブテンに混合して実験を行なった。解析は次の ように行なう。生成系の気相に存在する各異性体の持つ 放射性の比強度比を $A_{1}=I_{1}^{*} / I_{1}, A_{t}=I_{t}^{*} / I_{t}, A_{c}=I_{c} * / I_{c}$ とする。これらの值を時間の関数として求めた場合, 各 スキームに関して予想される挙動は，下表のようにな る。

表 3 放射能比強度比による反応スキームの判別

\begin{tabular}{|c|c|c|c|c|}
\hline \multirow{2}{*}{ 反 応 } & \multirow{2}{*}{\multicolumn{2}{|c|}{$\frac{\text { シスより出発 }}{A_{c}, A_{t} \lim _{t \rightarrow 0}\left(A_{t} / A_{1}\right)^{*}}$}} & \multirow{2}{*}{\multicolumn{2}{|c|}{$\frac{\text { トランスより出発 }}{A_{c}, A_{t} \lim _{t \rightarrow 0}\left(A_{c} / A_{1}\right)^{*}}$}} \\
\hline & & & & \\
\hline (1) & $A_{c}<A_{t}$ & 0 & $A_{c}>A_{t}$ & 0 \\
\hline (2) & $A_{c}<A_{t}$ & 1 & $A_{c}>A_{t}$ & 1 \\
\hline (3) & $A_{c}>A_{t}$ & 0 & $A_{c}>A_{t}$ & 0 \\
\hline (4) & $A_{c}<A_{t}$ & 0 & $A_{c}<A_{t}$ & 0 \\
\hline
\end{tabular}

* $\lim _{t \rightarrow 0}$ は反空時間零に外插を示す。

ただし，前提として速度定数相互の相違が，実験に使用 する放射性ブテンと通常ブテンとの混合比よりははるか に小さいものとする。結果は 図 12 に示した通り,

$\lim _{t \rightarrow 0} A_{t} / A_{1}=0 \lim _{t \rightarrow 0} A_{c} / A_{1}=0 \quad A_{t}>A_{c}$ で (1) また は (4) が明らかとなった。トランス-2-ブテンからの実 験結果がなく, 両者の最終判定は保留している。なお, $\mathrm{NaCl}$ を添加すると反応の誘導期が消失すること, $\mathrm{SnCl}_{2}$ を添加すると，溶媒のメタノールとブテン間で重水素交 換がおこることを考慮し，この触媒では，共通の反応中 間体として1-ブテン $\pi$ 錯体を考え，前者では，水素付加 


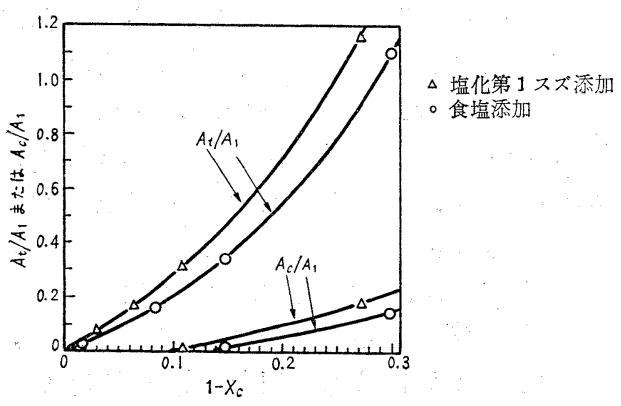

$X_{\mathrm{C}}$ は $n$-ブテン中のシス-2-ブテンのモル分率 ${ }^{14} \mathrm{C}$ 標識実験

a） シス-2-ブテン異性化反応における ${ }^{14} \mathrm{C}$ 濃度変化

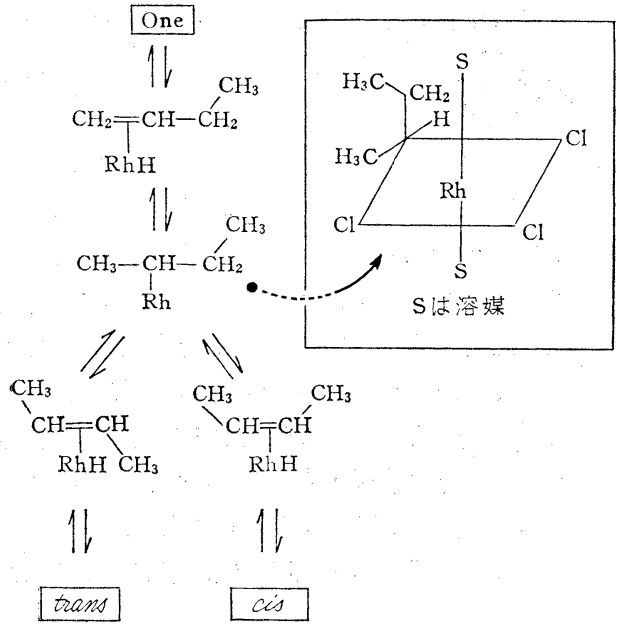

食塩添加の場合の反応機構

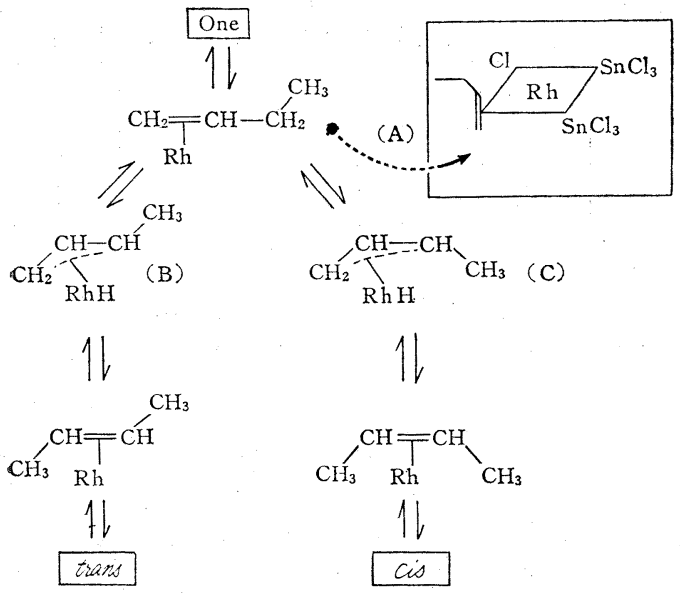

塩化第一スズ添加の場合の反応機構

b） 異性化反応機構

図 12 塩化ロジウム錯体による異性化
したアルキル錯体が，後者では，異性化が水素化よりも 極端に速いため水素付加はなく $\pi$ イアリル錯体のまま異 性化するとした（図 12)。

異性化反応にともなってオレフィン内にとり込まれる 重水素の位置の決定は，従来技術的な難点から行なわれ ていなかった。Seyffarth らは質量分析スペクトルを, 田丸らはマイクロ波スペクトルの解析により巧妙にその 位置の決定を行ない反応機構推定の決め手としている。

まず Seyffarth ら ${ }^{200}$ は，硫酸マグネシウムを乾燥へリ ウム気流中で処理し, 助触媒として $\mathrm{HCl}(\mathrm{DCl})$ を用い て1ーブテン異性化実験を行なった。この場合, 生成す る 2-ブテンには, $\mathrm{H}_{3} \mathrm{C}^{1}-\mathrm{C}^{2} \mathrm{H}=\mathrm{C}^{3} \mathrm{H}-\mathrm{C}^{4} \mathrm{H}_{3}$ であるから， $\mathrm{C}^{1}, \mathrm{C}^{4}$ に 3 個, $\mathrm{C}^{2}, \mathrm{C}^{3}$ に 1 個の重水素の大る位置があ る。分析条件を適当に選んで，主として脱メチルのみが 起るようにすれば， $\mathrm{C}^{1}$ または $\mathrm{C}^{4}$ のみが切断されたフ ラグメントが出てくる。(i) 異性化反応の結果, $\mathrm{C}^{1}$ また は $\mathrm{C}^{4}$ のみに Dが大る場 合の生成物, $\mathrm{H}_{2} \mathrm{DC}-\mathrm{CH}=\mathrm{CH}$ $\mathrm{CH}_{3}$ からは

$\mathrm{H}_{3} \mathrm{C}-\mathrm{CH}=\mathrm{CH}^{+}$ $[6]$

質量数 41

$\mathrm{H}_{2} \mathrm{DC}-\mathrm{CH}=\mathrm{CH}^{+}$ [7]質量数 42

なるフラグメントが確率 1:1 で出てくる。生成した, ある2-ブテン中の重水素化率 $\mathrm{F}_{56}=\mathrm{D}_{57} /\left(\mathrm{D}_{57}+\mathrm{H}_{56}\right)$ と, プロペニル中の重水素化率 $\mathrm{F}_{41}=\mathrm{D}_{42} /\left(\mathrm{D}_{42}+\mathrm{H}_{41}\right)$ を比較 すると，この場合

$\mathrm{F}_{41}=1 / 2 \mathrm{~F}_{56}$

になることが容易的かるであらら。(ii) むし重水素が $\mathrm{C}^{2}$ または $\mathrm{C}^{3}$ に入った場合には, 生成するフラグメン 卜は, $\mathrm{C}^{1-} \mathrm{C}^{2}$ が切れても， $\mathrm{C}^{3}-\mathrm{C}^{4}$ が切れても

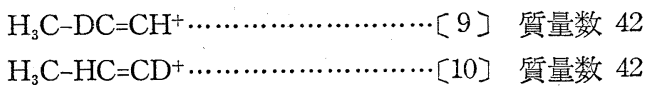

であるから, 同じ質量数 42 となり, フラグメントを起 す前の重水素化率 $\mathrm{F}_{56}$ とプロペニルの重水素化率は同じ である。したがって,

$\mathrm{F}_{41}=\mathrm{F}_{56}$

ところが実験 結果は， $F_{41} / F_{56}$ が 0.75 に近い值となっ た。この結果を次のように解釈する。重水素が $\mathrm{C}^{1}$ また は $\mathrm{C}^{4}$ に入る場合 [8] と, $\mathrm{C}^{2}$ または $\mathrm{C}^{3}$ に入る場合 [11]の出現確率が同等であると仮定すると， $\mathbb{F}_{41}=3 / 4$ $\mathrm{F}_{56}$ になることが明らかである。そこで彼等は, $\mathrm{C}^{1}, \mathrm{C}^{2}$ へDの入る確率が等しくなるような機構として図 13 に 示すような，水素ブリッジ型錯体を推定した。ここで， $\mathrm{D}$ と $\mathrm{H}_{21}$ 注全く等価であり, 実験結果を最も簡単に説明

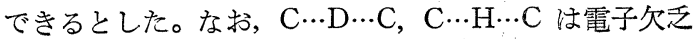
型の結合で同様な例として， $\mathrm{B}_{2} \mathrm{H}_{6}$ を頭においている。 触媒上の水素はプロトン的性質を持つと考えられるか 


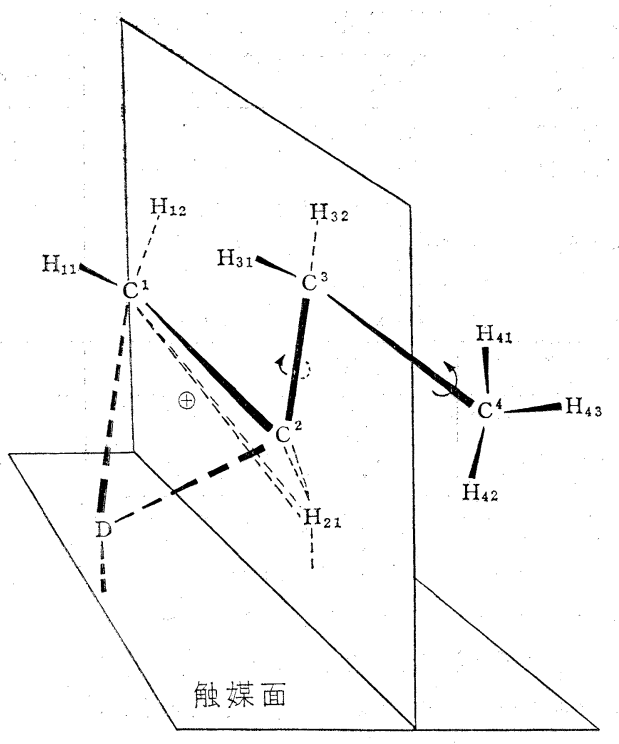

图 13 水素ブリッジ型錯体のモデル (Seyffarth)

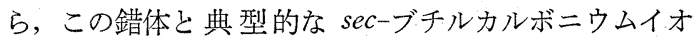
ンとの相異は，プロトンが $\mathrm{C}^{1}$ または $\mathrm{C}^{2}$ に完全に所属 しているか否かの点だけとなる。また D-ブテンとして 脱離するためには，さらにひとつのプロトンを引きぬか ねばならないが，タイミングの違いで，ブチルカルボニ ウムイオン機構と水素スイッチ機構とにわかれる。しか し，この場合には，後述するような $\mathrm{C}^{3}$ 位からの協奏的 な水素引き好きは困難が予想される。これは，かって提 唱された， $\pi$ 電子一プロトン錯体と同類のものと考えら れるが，特定のブリッジ構造を与えている点が新しいと みられる。水素ブリッジ説のキィーポイントは $\mathrm{C}^{1}$ 位と $\mathrm{C}^{2}$ 位の水素付加が 同等に起ることであるが，触媒上で の直接または触媒面を通しての $\mathrm{C}^{1}, \mathrm{C}^{2}$ 位の水素交換が 異性化比比べてきわめて速い場合, フラグメントを生成 する段階での水素の移行などが無視できない場合には確 認できなくなる。また同位元素効果や，塩化水素の触媒 上での状態などに対する検討がほしいが，マススペクト ルを巧く利用した点で興味深い。

一方田丸ら ${ }^{211}$ は，1-ブテン中の重水素の位置をマイク ロ波スペクトルから決定できることに着目し， $\mathrm{C}^{1} \sim \mathrm{C}^{3}$ 間の水素スイッチ機構の存在を証明した。すなわち，筆 者らが典型的なプロトン酸型固体酸触媒のひとつとして 見出した $p$-トルエンスルホン酸結晶を用い，予禹水 処理して表面の $\mathrm{H}^{+}$を $\mathrm{D}^{+}$に置換し，シス-2-ブテンの 異性化を行なった。生成する 1-ブテン中のDの位置は， 図 14 に示したように，まず $\mathrm{C}^{3}$ の位置に $100 \%$ 入り， $\mathrm{H}_{\mathrm{a}}$ または $\mathrm{H}_{\mathrm{b}}$ に入ることがわかった。また $\mathrm{H}_{1 \mathrm{a}}, \mathrm{H}_{\mathrm{ib}}$ ，
$\mathrm{H}_{2}, \mathrm{H}_{4 \mathrm{a}}, \mathrm{H}_{4 \mathrm{~b}}, \mathrm{H}_{4 \mathrm{c}}$ の位置には全く入らず, 転化率の上 昇とともに, $\mathrm{H}_{3}-\mathrm{d}_{1}$ ( ( $\mathrm{C}^{3}$ 位に 1 個 Dが入ったもののブテ ン）の減少掠よび $\mathrm{d}_{0}$ (全く重水素の入らぬブテン) の 増加にともなって $\mathrm{H}_{2}-\mathrm{d}_{1}$ ができてくることがわかった。 一方, トランス-2-ブテンを出発物質としても全く同様 な結果であるが，1-ブテンを出発物質としたときには， 平衡転化率に近ずいても気相にはわずか $2 \%$ 程度しか $\mathrm{H}_{3}-\mathrm{d}_{1}$ がみられず，単純交換にともな5 $\mathrm{C}^{3}$ 位へのDの とり込みはほとんどなく，2-ブテンからの逆反応からの み入るものと思われる。 $\mathrm{C}^{2}$ 位には全く $\mathrm{D}$ は入らず， $\mathrm{C}^{4}$, $\mathrm{C}^{1}$ にはかなり D が入り得ることがわかった。典型的な ルイス酸型固体酸触媒とみられるアルミナ上では全く D がとり込まれず，シリカーアルミナでは約 $90 \%$ は重水 素化できず約 $10 \% の \mathrm{H}_{3}-\mathrm{d}_{1}$ にDが入った。この結果は, $\mathrm{C}^{1} \sim \mathrm{C}^{3}$ 間で水素スイッチ機構が プロトン酸では妥当で あるが，ルイス酸ではスイッチ機構は存在しないこと， シリカーアルミナでは，スイッチ機構と，その他の機構 が共存すると考えた。このことは，シリカーアルミナ上 の活性点が，プロトン酸点のみならずルイス酸点も共存 することに対応している。

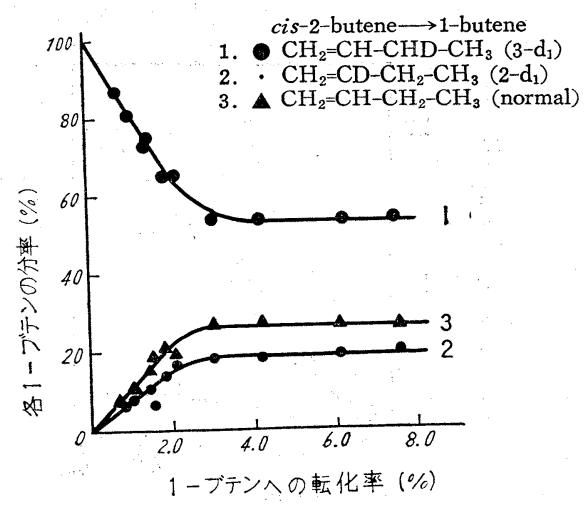

触媒 $p$-トルエンスルホン酸結晶/ンリカゲル（重水処理） 反応 $20^{\circ} \mathrm{C}$ 位置決定は下図 (1-ブテン)

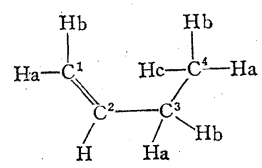

(Da)

図 14 .重水素化ブテン組成の経時变化

最近御園生ら ${ }^{22)}$ は，(図 8a) のsec-ブチルカルボニウ ムイオンを共通の反応中間体であると仮定し, 異性化に ともなら水素の挙動に関して，やや別の見方をしてい る。今, 触媒表面を重水处理し, $\mathrm{H}^{+}$を $\mathrm{D}^{+}$で置換して おくものとする。たとえば，異性化の進行にともなって 触媒から生成オンフィンにDが入るときには，Ha の位 
置が Da になるものとする。カルボニウムイオンにおい て，(i) 水素の移動，(ii） $\mathrm{C}^{2}-\mathrm{C}^{3}$ 軸に関して $\mathrm{C}^{1}, \mathrm{Hd} の$ 回転がいずれも存在しない場合には，Hc の脱離で 1$\mathrm{C}_{4} \mathrm{H}_{7} \mathrm{D}$ が, $\mathrm{Ha}$ の脱離で cis- $\mathrm{C}_{4} \mathrm{H}_{7} \mathrm{D}$ が, $\mathrm{Hb}$ の脱離で trans $-\mathrm{C}_{4} \mathrm{H}_{7} \mathrm{D}$ が生成するものと考えられる。もし，(i) または（ii）のいずれかが存在するときには， $\mathrm{Ha}$ と $\mathrm{Hb}$ の 2 つは等価になってしまい, シス $-\mathrm{d}_{1} /$ シス $-\mathrm{d}_{0}$ とトラ ンス $-\mathrm{d}_{1} /$ トランス- $\mathrm{d}_{0}$ の比は全く等しくなる。ただし， $\mathrm{d}_{1}$ は重水素の 1-置換体, $\mathrm{d}_{0}$ は重水素の全く入らぬもの を示す。同位体効果が全くない場 合を考えるとき，(i) の水素交換が $\mathrm{Hd}, \mathrm{Ha}, \mathrm{Hb}$ の間で速いときには, シス$\mathrm{d}_{1} /$ シス $-\mathrm{d}_{0}=$ トランス $-\mathrm{d}_{1} /$ トランス $-\mathrm{d}_{0}=2 / 3$ (NMR で測 定したこの交換速度は，2,3-ジメチルブチルカチオン $\left(-85^{\circ} \mathrm{C}\right)$ の場合 $10^{-4} \mathrm{sec}^{-1}$ の大きさであるという報告が ある）となる。また, (ii) の $\mathrm{C}_{2} \sim \mathrm{C}_{3}$ 間の回転が十分速 いときには，シス $-\mathrm{d}_{1} /$ シス $-\mathrm{d}_{0}=$ トランス $-\mathrm{d}_{1} /$ トランス $-\mathrm{d}_{0}$ $=1 / 2$ となる。一方, 1-ブテンの生成には必ず触媒から $\mathrm{D}$ をろらから，1-ブテン $-\mathrm{d}_{1} / 1$-ブテン $-\mathrm{d}_{0}=\infty$ となる ことが予想される。ここで Hall らのシリカーアルミナ 上で重水素化ブテンと通常ブテン $1: 1$ に混合比の結果 老用いて計算を行ない, 図 15 に示すように, 反応初期

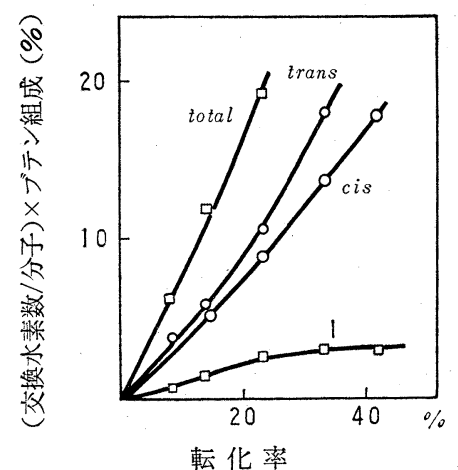

図 15 重水素化ブテンの絶対量へ転化率の関係 シス-2-ブテン (シリカーフルミナ) $19^{\circ} \mathrm{C}$ 反応

には, シス, トランス-2-ブテンの重水素化がほぼ同程 度に進行すること, また各ブテンの転化率 0 における重 水素化率は 0.5 付近の值となり, $\mathrm{Ha}$ と $\mathrm{Hb}$ が等価であ ると結論した。さらに, 1 次の速度論的同位体効果を考 慮して解析をしなおすことを試みた。プロトン付加につ いての $1 / \mathrm{a}$, 脱離について $1 / \mathrm{b}$ と同位体効果が表わせ, D酸点の数とH酸点の数の比を $r$ とするとき, 各反応 についての相対速度比を算出したものが 表 4 である。 $f=\mathrm{C}_{4} \mathrm{D}_{8} / \mathrm{C}_{4} \mathrm{H}_{8}$ 法出発時の比。 $\mathrm{e}$ 注反応機構の (1), （2）の性格できまるパラメータで，付加した $\mathrm{H}^{+}$または $\mathrm{D}^{+}$が別の $\mathrm{H}^{+}$または $\mathrm{D}^{+}$を脱離する確率。(たとえば,
表 4 同位体効果を考慮した相対速度解析

\begin{tabular}{|c|c|c|c|}
\hline 反 & 応 & 相対速度 & 生成ブテン \\
\hline $\mathrm{C}_{4} \mathrm{H}_{8}+\mathrm{H}^{+} \longrightarrow$ & $\mathrm{C}_{4} \mathrm{H}_{8}+\mathrm{H}^{+}$ & 1 & $\mathrm{~d}_{0}$ \\
\hline $\mathrm{C}_{4} \mathrm{H}_{8}+\mathrm{D}^{+} \longrightarrow$ & $\mathrm{C}_{4} \mathrm{H}_{8}+\mathrm{D}^{+}$ & $\mathrm{arb} /(1+\mathrm{e})$ & $\mathrm{d}_{0}$ \\
\hline & $\mathrm{C}_{4} \mathrm{H}_{7} \mathrm{D}+\mathrm{H}^{+}$ & are $/(1+e)$ & $\mathrm{d}_{1}$ \\
\hline $\mathrm{C}_{4} \mathrm{D}_{8}+\mathrm{H}^{+} \longrightarrow$ & $\mathrm{C}_{4} \mathrm{D}_{7} \mathrm{H}+\mathrm{D}^{+}$ & $\mathrm{bef} /(1+\mathrm{e})$ & $\mathrm{d}_{7}$ \\
\hline & $\mathrm{C}_{4} \mathrm{D}_{3}+\mathrm{H}^{+}$ & $\mathrm{f} /(1+\mathrm{e})$ & $\mathrm{d}_{8}$ \\
\hline $\mathrm{C}_{4} \mathrm{D}_{8}+\mathrm{D}^{+} \longrightarrow$ & $\mathrm{C}_{4} \mathrm{D}_{8}+\mathrm{D}^{+}$ & arbf & $\mathrm{d}_{8}$ \\
\hline 計 算 值 & $1 / b$ & $\overline{a r}$ & $\mathrm{e}$ \\
\hline $1-\mathrm{C}_{4} \mathrm{H}_{8}$ 生成 & 1.9 & 0.64 & $\infty$ \\
\hline $\begin{array}{r}\text { trans }-2-\mathrm{C}_{4} \mathrm{H}_{8} \\
\text { 生成 }\end{array}$ & $1.4_{5}$ & 0.71 & 2.9 \\
\hline
\end{tabular}

反応毎に必ず場合には e はのとなる）計算結果は，下闌 のようになり，トランス-2-ブテン生成に関して, $e=$ 2.9 なる值が得られた。この值は, $\mathrm{C}^{2} \sim \mathrm{C}^{3}$ 間の軸回転 が速いとする仮定よりむしろ， $\mathrm{C}^{2} \sim \mathrm{C}^{3}$ 間でのH移行が 速いとする可能が強いことを意味している。また，1-ブ テン生成では，反応各に毎回必ず水素交換がおこること が期待されることもわかった。

以上三つの研究例は, 同位元素をトレーサーにして, 解析方法を工夫することにより，単に重水素の授受だけ でなく, その位置を判定することから反応機構の解明を 試みたものであり，仮定と解釈に誤りさえなければ有力 な手段のひとつである。

\section{V. 固体塩基触媒によるブテン異性化反応}

前章まで述べた研究はいずれも固体酸触媒を中心とし た触媒系であるが，固体塩基触媒についての研究例は比 較的少ない。Haag, Pines ら ${ }^{\tau \mathrm{b})}$ は, 例によって, Na-ア ルミナ系触媒での相対反応速度を求めた（図 16)。1-ブ

$$
\text { cis- } \mathrm{C}_{4} \mathrm{H}_{8} \frac{12.3}{\rightleftharpoons_{3.6}} \operatorname{trans}-\mathrm{C}_{4} \mathrm{H}_{8}
$$

図 $16 \mathrm{Na}-\mathrm{Al}_{2} \mathrm{O}_{3}$ 触媒での相対反忘速度定数 テン異性化でシス体生成がトランス体の 4 倍もあること に関して, 中間体として考えられるブテニルカルボニウ ムイオンは,

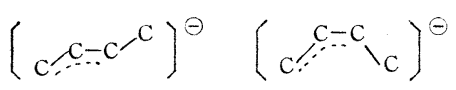

で,より安定なシス型錯体を経由しているものとして Foster らと同意見である。また, $\mathrm{Na}^{+}$と $\mathrm{Li}^{+}$とでは $\mathrm{Li}^{+}$ の方がシス選択性が小さいことの原因としてアルカリ金 属カチオンが介在したブリッジ型構造をとって安定化 し, $\mathrm{Na}^{+}$と $\mathrm{Li}^{+}$では $\mathrm{Li}^{+}$のイオン半径が小さすぎるた 
め安定化の度合が少ないと想像した。

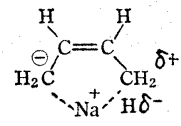

表 5 オレフィン巽性化選択性に対する溶媒および塩基の効果

\begin{tabular}{|c|c|c|c|}
\hline 塩 & 媒 & $\begin{array}{l}\text { 活 性 } \\
k \times 10^{8} \\
\mathrm{sec}^{-1}\end{array}$ & $\begin{array}{l}\text { 選択率 } \\
\mathrm{i}_{\mathrm{t}}{ }^{\mathrm{c}} \\
\mathrm{time} \rightarrow 0\end{array}$ \\
\hline & 1 -ブテン $55^{\circ}$ & & \\
\hline $\mathrm{NaO}-t-\mathrm{Bu}$ & DMSO & 0.01 & 37 \\
\hline $\mathrm{KO}-t-\mathrm{Bu}$ & DMSO & 1.16 & 26 \\
\hline $\mathrm{RbO}-t-\mathrm{Bu}$ & DMSO & 2.84 & 16 \\
\hline $\mathrm{CsO}-t-\mathrm{Bu}$ & DMSO & 4.47 & 25 \\
\hline $\mathrm{KO}-t-\mathrm{Bu}$ & TMU & 0.0174 & 23 \\
\hline $\mathrm{KO}-t-\mathrm{Bu}$ & $\mathrm{N}$-methyl-2-pyrrolidone & 0.0785 & 26 \\
\hline $\mathrm{KO}-t-\mathrm{Bu}$ & $\begin{array}{l}\mathrm{HMPA} \\
\quad 1 \text {-ペンテン } 55^{\circ}\end{array}$ & 0.201 & 19 \\
\hline $\mathrm{KOMe}$ & DMSO & 0.00569 & 14 \\
\hline $\mathrm{KO}-t-\mathrm{Bu}$ & DMSO & 0.717 & 13 \\
\hline $\mathrm{KO}-t-\mathrm{Bu}$ & $\mathrm{DMSO}+0.5 \% t-\mathrm{BuOH}$ & 0.605 & 11 \\
\hline $\mathrm{KO}-t-\mathrm{Bu}$ & $\mathrm{DMSO}+1 \% t-\mathrm{BuOH}$ & 0.493 & 10 \\
\hline $\mathrm{KO}-t-\mathrm{Bu}$ & $\mathrm{DMSO}+2 \% t-\mathrm{BuOH}$ & 0.433 & 10 \\
\hline $\mathrm{KO}-t-\mathrm{Bu}$ & $\mathrm{DMSO}+4 \% t-\mathrm{BuOH}$ & 0.256 & 10 \\
\hline $\mathrm{KO}-t-\mathrm{Bu}$ & $\mathrm{DMSO}+8 \% t-\mathrm{BuOH}$ & 0.044 & 10 \\
\hline
\end{tabular}

1) DMSO:ジチルスルホキント

2) TMU:テトラメテル崉素

3） HMPA：へキサメチルホスホラミド

Bank ら ${ }^{23)}$ は, DMSO あるいは, $\mathrm{DMSO}+t-\mathrm{BuOH}$ を用いた均一系において ter-ブトキシアルコラート (MO- $t-\mathrm{Bu} ; \mathrm{M}=\mathrm{K}, \mathrm{Rb}, \mathrm{Cs}$ など) を触媒とし，一連の 実験を行なった。結果は 表 $\mathbf{5}$ に示す。ここで均一系で はあるが強塩基触媒と考えられる系で, シス-選択性が 極端に大きく，トランス-2-ブテンはほとんど生成しな いといえる程度であることに注目してほしい。彼らは, アルカリ金属をかえても, 溶媒をかえてイオン対の解離 度を変化させても, 速度の変化の大きさに比べて, 選択 性はほとんど変動しないことから, 共通の中間体である ブテニルカルバニオン自身が, 熱力学的に安定化してい るためと主張した。気体のブテン分子においては，トラ ンス体の方が安定であることが知られているが，ブテニ ルカルバニオンでは，メチル基の双極子の作用でむしろ シス体の方が安定化しているものと考えた。<smiles>CC=CC</smiles><smiles>CC=CC</smiles>

Bank らの考えている反応機構は, 図 17 に示した通 りで固体酸の場合の，1-ブテン経由の機構と全く類似し ている。すなわち， $k_{5}>k_{-5}$ であるが，他の速度定数よ
り十分小さいとみている。異なる点としては, 重水素化 オレフィンを共存させて反応を行なうと, 大きな同位体 効果が見られ，しかも，溶媒や，オレフィンへのDの交 換はわずかであったことから，他の多くの不均一系触媒 とは別に, 分子内 $\mathrm{C}^{3} \sim \mathrm{C}^{1}$ 間の水素シフトによるもので あるとしている。最近金井ら ${ }^{37)}$ は，金属イオンにより選 択性がかなり変化することに着目して, 遷移金属ホスフ イン錯体と水素源としての $\mathrm{NaBH}_{4}$ との組み合わせで配 位子効果を中心としての一連の研究を行なっているが詳 細は原報をみられたい。

固体塩基触媒として, 最近アルカリ土類の酸化物, $\mathrm{MgO}, \mathrm{CaO}, \mathrm{SrO}$, などが注目をあび出しており, 塩基 性の測定も行なわれている ${ }^{24)}$ 。またこれら酸化物の焼成 雲囲気や，異種金属イオン添加によって，物性や触媒活 性が大きく変化することが明らかにされて来ている。酸 化カルシウムに関しては, $500 \sim 600^{\circ} \mathrm{C}$ での真空脱気で, シスー2-ブテン異性化活性と，その選択性のトランス-2ブテン/1-ブテンの值の平行的な急増がみられ, 脱炭酸 との対応が考えられている ${ }^{25)}$ 。

酸化マグネシウムに関しての筆者ら ${ }^{26)}$ の実験 結 果 で は，塩基性炭酸マグネシウムの熱分解は，空気中で段階 的におこり, DTA では, $560^{\circ} \mathrm{C}$ ではじめて完全な $\mathrm{MgO}$ になるが, $700^{\circ} \mathrm{C}$ まで焼成しても, 表面積, 活性, 選択 性, 活性化エネルギーはほとんど大差がなく，表面はか なり安定化するものと思われる。また, 塩基性点に, 強 度の異なるものが存在することは, 反応にともなう活性 の低下が，一定レベルで停止し，選択性などの変化がみ られたことから推定される。すなわち, 反応によって, 容易に被毒されやすい活性点と, ほとんど被毒をらけな 、活性点とが存在し, 前者は後者にくらべて, トランスー 2-ブテンへの異性化, シスートランス異性化が相対的に 大きいことが示唆されている。固体塩基触媒に関して は，目下各種の研究が進行中の段階であるので，機会を 改めて，まとめてみたい。
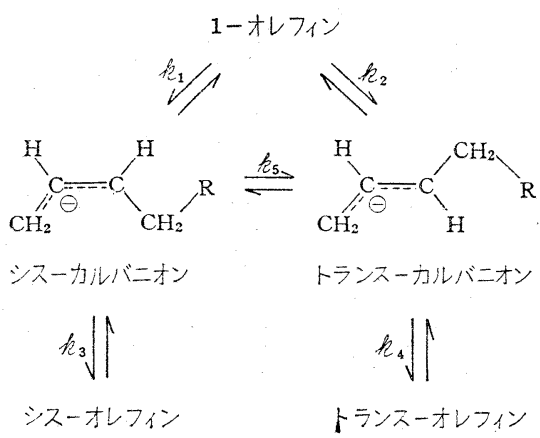

図 17 カルハトニオン機構 (Bank) 


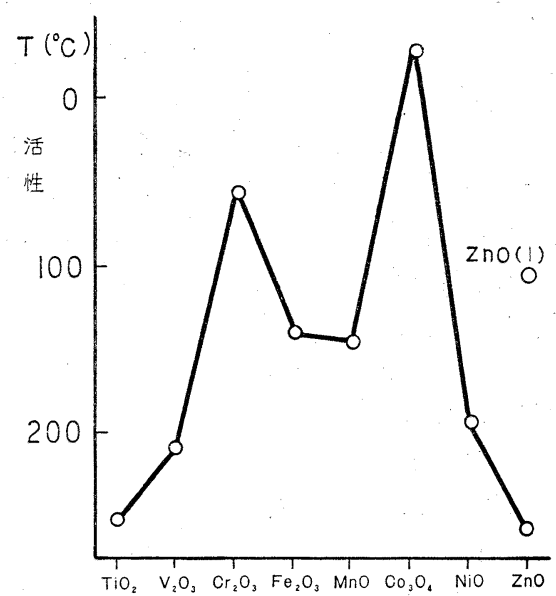

a. ブテン異性化 (シスー2-ブテン)

活性は 1 次反応速度定数が $10^{-5} \mathrm{sec}^{-1} \mathrm{~cm}^{-2}$ になる温度を用いた。 $\mathrm{ZnO}$ (I) は試薬の $\mathrm{ZnO}$ を $450^{\circ} \mathrm{C}$ 酸素霉囲気で焼成し， $300^{\circ} \mathrm{C} て$ 脱気したもの。

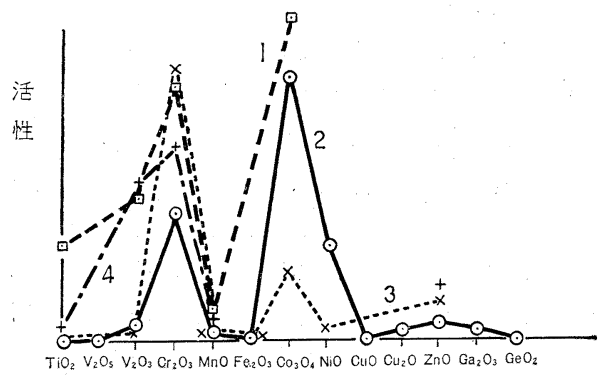

b. Dowden パターン

活性は任意尺度

1: シクロヘキサン不均化 $\left(200 \sim 450^{\circ} \mathrm{C}\right)$

$2: \mathrm{H}_{2} \sim \mathrm{D}_{2}$ 交換 $\left(80^{\circ} \mathrm{C}\right)$

3 : エチレン水素化 $\left(-120 \sim 400^{\circ} \mathrm{C}\right)$

$4:$ プロパン脱水素 $\left(550^{\circ} \mathrm{C}\right)$

図 18 遷移金属酸化物の活性パターン

\section{VI. 半導体触媒によるブテン異性化}

金属酸化物, 特に複合酸化物の中には, 濃硫酸に匹敵 し，あるいはしのぐほどの強い表面酸性を示すものがあ ることは, シリカーアルミナ触媒を想起すれば明らかで あり，一方きわめて強、表面塩基性を持つむのも見出さ れてきている。金属イオンの電気陰性度をひとつの尺度 とすれば, $\mathrm{Fe}^{3+}, \mathrm{Th}^{4+}, \mathrm{Cr}^{3+}, \mathrm{Al}^{3+}$ などは強いルイス酸 性を示し, $\mathrm{Na}^{+}, \mathrm{Li}^{+}, \mathrm{Ba}^{2+}, \mathrm{Ca}^{2+}$ などは酸性はきわめて 弱いことがわかる。酸化物や, 硫化物となった場合, そ の表面に発現する酸-塩基性は, 必らずしも単純にイオ ンの酸塩基性を尺度とはできないし，特に，複合酸化物 の場合そうである。一般に電気陰性度の尺度で中位に属
する $\mathrm{Zn}^{2+}, \mathrm{Cd}^{2+}, \mathrm{Pb}^{2+}, \mathrm{Ni}^{2+}$ などの酸化物では，特に 強い酸-塩基性を見出されることなく，いわゆる典型的 な固体酸，固体塩基触媒の部類には入れない。むしろこ れらの酸化物は，遷移金属酸化物として別の触媒グルー プを形成している。そのうち, 酸化亜鉛や, 酸化ニッケ ルは, 酸化物型半導体としての代表的なものであり, $\mathrm{n}$ 型半導体， $\mathrm{p}$ 型半導体としての特性をむっている。これ らの酸化物上の吸着や触媒作用に関して, 電導度の変化 などから関心が持たれたが，半導体触媒といら用語を用 いるのは見解の相異が持たれるところである。

図 18a は，第 4 周期の $\mathrm{Ti}$ から $\mathrm{Zn}$ までの遷移金属 の酸化物を用いたブテン異性化に関する活性パターンを 示したものである27)。類似のパターンとしてすぐに思い 出されるのは, Dowden のパターンである。詳細は最近 Dowden の総説 ${ }^{28)}$ が出ているので参照願うとして, 図 $18 \mathrm{~b}$ に示すように, シクロへキサン不均化, $\mathrm{H}_{2} \sim \mathrm{D}_{2}$ 交換, プロパン脱水素, エチレンの水素化反応などに対して全 く類似した双頭ピークを持つ活性パターンを示すことが わかる。Dowden はこの原因を結晶場の理論から解釈を 試みているが，いずれにしても，反応例をみると，水素 の関与している反応であることに注目される。窪川ら ${ }^{27)}$ によれば，ブテン異性化が水素の存在しない系なので, 水素の付加した $\sigma$ アアルキル錯体を考えるよりも，金属 イオンとオレフィンの $\pi$ 電子間の相互作用を考慮した ாーアリル錯体を考えるのが妥当であるらとしている。も っとも，酸化物の製法や，前処理が異なり，反応条件の 影響を除外していない温度を尺度にしているので, パタ ーンの形状の厳密な論議はできない。たとえば，図 18a 中の酸化亜鉛は, 試薬を予め $450^{\circ} \mathrm{C}$ で焼成し, $300^{\circ} \mathrm{C}$ で 脱気したものでは, 活性が極端に上昇している。素性不 明の酸化亜鉛に衫ける異性化反応は, Foster $\left(550{ }^{\circ} \mathrm{C}\right)$ やSvetanovic $\left(500^{\circ} \mathrm{C}\right)$ などにも現われているが，筆者 らは，より低い温度での反応を熱分解酸化亜鉛で行なっ $\tau^{299}$, 活性, 選択性とも熱分解時の影響をきわめて敏感 にうけることがわかった。図 19a はドーピングの効果 をみたもので, $\mathrm{Ga}^{3+}$ や $\mathrm{Al}^{3+}$ を導入すると, 活性の上昇 とシスートランス異性化の選択性が大きくなり, $\mathrm{Li}^{+}$添加 では逆に明らかに減少した。また硫化亜鉛に関しても30) 活性は酸化亜鉛と同じ挙動を示し，選択性は少量添加の ときのみ上昇した(図 19b)。酸化亜鉛や硫化亜鉛が弱、 酸性を示すことが知られて招り，3価イオンの導入によ って表面酸度の数も増加することが明らかになったが， 測定された酸点との直接的な定量的関係はみられず，活 性点を単純に酸点ということはできない。

また，一般にブテン異性化反応を通常の反応条件で行 


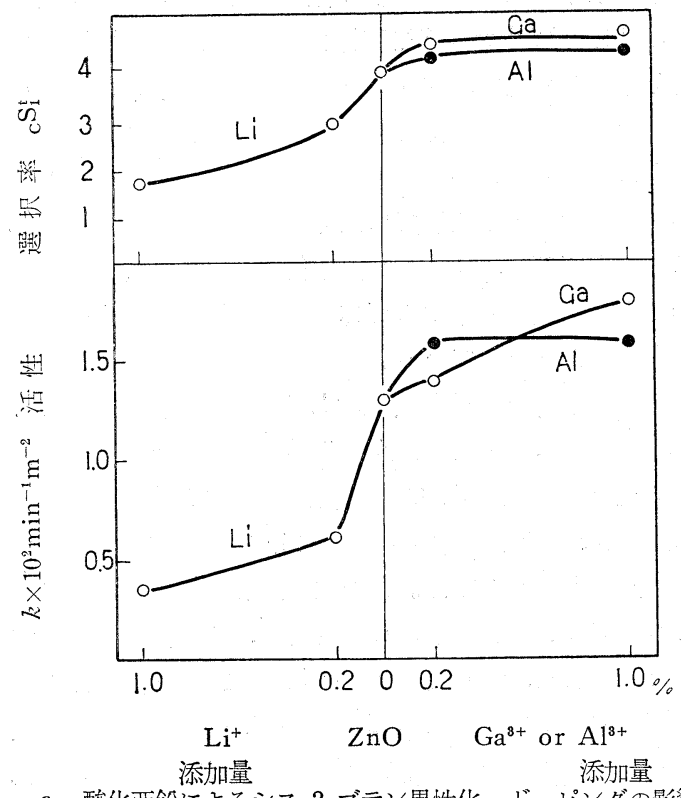

a 酸化亜鉛によるシス-2-ブテン異性化 ドーピソグの影響

$k: 320^{\circ} \mathrm{C}$ 反応 速度定数

$\mathrm{CS}_{1}{ }^{\mathrm{t}}=$ trans 11 ( $300^{\circ} \mathrm{C}$ 反応)

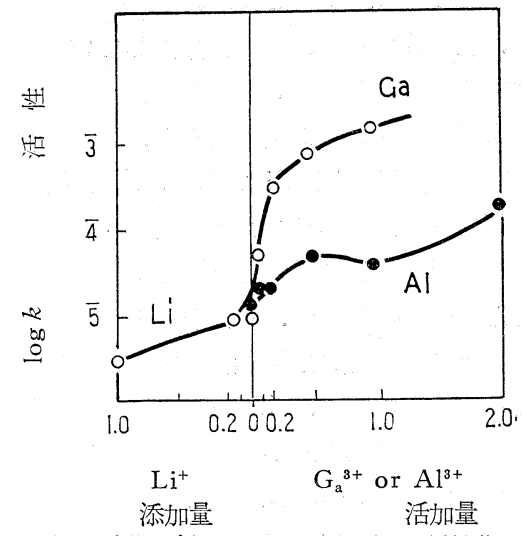

b 硫化亜鉛によるシスー2-ブテン異性化 ドーピングの影響

$k: 250^{\circ} \mathrm{C}$ 反応速度定数 $\left(\mathrm{min}^{-1} \mathrm{~m}^{-2}\right)$

図 19

ならとき, $\mathrm{H}_{0} \leqq 1.5$ 程度の酸強度が必要と思われるの に，こ扎らの触媒では相当する酸強度はきわめて少ない こと,アンモニア被毒で活性を完全には消失しないこ と, 酸素や水素を気相あるいは，吸着により共存させる と，硫化亜鉛では活性点は酸性点以外のものが主である うと考えた。したがって，固体酸の場合に提出されたブ チル，あるいはブテニルカルボニウムイオンを考えるよ

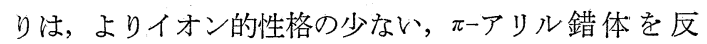
応中間体に考劣る方が妥当のようである。

田丸ら ${ }^{31}$ は，水素共存下で 進行する $n$-ブテンの水素

化と異性化反応は独立の速度挙動を示すこと，1-ブテン から直接トランス-2-ブテンへの異性化が起らないこと などから

$\mathrm{C}_{4} \mathrm{H}_{10} \longleftarrow 1-\mathrm{C}_{4} \mathrm{H}_{8} \rightleftarrows$ cis- $\mathrm{C}_{4} \mathrm{H}_{8} \rightleftarrows$ trans $-\mathrm{C}_{4} \mathrm{H}_{8} \cdots[12]$ なるスキームを考えている。また，水素化に際しての水 素は分子状に近いかたちで必ずペアで作用することなど を明らかにしている。

Kokes らは，金属酸化物上のオレフィン二重結 合移

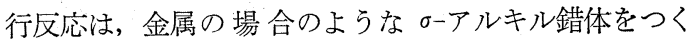
るのはむづかしいと考え, 酸化亜鉛上のオレフィン吸着 が $\pi$ アリル錯体であることを, 重水素をトレーサーと してプロピレンの吸着を行なって推定した ${ }^{32)}$ 。なお ち、IR スペクトルより，プロピレン吸着が次の機構で 表わせることを明らかにした（図20）。

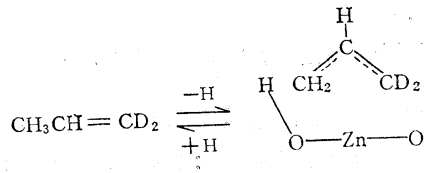<smiles>C=[NiH+]</smiles>

$\mathrm{CH}_{2}=\mathrm{CH}-\mathrm{CD}_{2} \mathrm{H}$

$\mathrm{CH}_{2} \mathrm{D}-\mathrm{CH}=\mathrm{CDH} \underset{-\mathrm{D}}{\stackrel{+\mathrm{D}}{\rightleftharpoons}} \mathrm{O}-\mathrm{Zn}-\mathrm{O}^{\mathrm{C}}$<smiles>C#C[Pt]=C</smiles>

図 20 酸化要鉛上のプロピレン吸着と D-H 交換

また酸化亜鉛の $\mathrm{OH}$ 振動領域の IR スペクトルを 図 21 に示す ${ }^{33)}$ 。1-ブテンを導入すると $\mathrm{ZnOH}$ の $\mathrm{OH}$ に 相当する $3615 \mathrm{~cm}^{-1}$ ピークが $5 \mathrm{~cm}^{-1}$ ほど低波数側に シフトし, 新しく, $3587 \mathrm{~cm}^{-1}$ 付近に $\mathrm{OH}$ に相当する ピークが出現する。これは, 長時間脱気してもかなり安 定であり，ブテンより脱 $\mathrm{H}$ して生成したものと思われ， プロピレンの場合と類似していた。図21bに示したピー クのうち, $3082 \mathrm{~cm}^{-1}$ は気相 1-ブテン $\left(3086 \mathrm{~cm}^{-1}\right)$ に

a

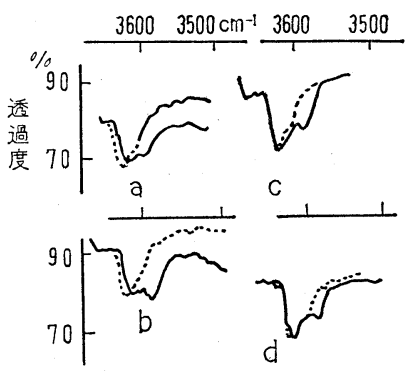

点線: 䙸入前, 実線: 1-ブテン $(8 \mathrm{~mm} \mathrm{Hg})$ 導入後 a) 8 分 b) 60 分 c) 70 分，その後

図 21 酸化亜鉛上の吸着ブテンの IR スペクトル 
b

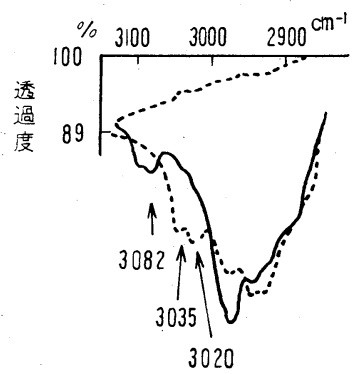

a

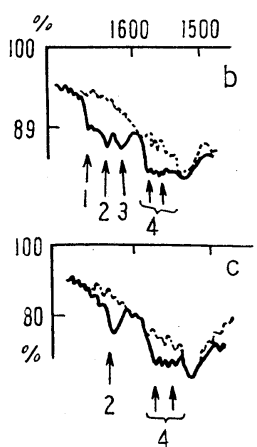

a 実線 : 1-ブテン $(8 \mathrm{mmHg})$ 遒入後10分 点線 :

b 点線：導入前 実線：導入後 20 分

c 実線: 導入後 70 分

$\begin{array}{lll}\text { 1. } 1655 \mathrm{~cm}^{-1} & \text { 2. } 1630 \mathrm{~cm}^{-1} & \text { 3. } 1610 \mathrm{~cm}^{-1}\end{array}$

4. $1550 \sim 1570 \mathrm{~cm}^{-1}$
近い物理吸着ピークであるが，放置するらち消失し，対 応して $3035 \mathrm{~cm}^{-1}$ (シス-2-ブテン: 3030 ), $3020 \mathrm{~cm}^{-1}$ （トランス-2-ブテン：3021）が出現し，異性化反応の 進行したことがわかる。また $1655 \mathrm{~cm}^{-1}$ は気相 1-ブテ ン (1645)；1630 $\mathrm{cm}^{-1}, 1610 \mathrm{~cm}^{-1}$ の帰属は不詳である が，1550 1570 $\mathrm{cm}^{-1}$ に出現してくる吸着を彼らは $\pi$ アリル錯体によるものと考えている。また，この吸着錯 体の安定性については, 昇温脱離したブテンの組成をし らべ，その温度の平衡值よりも多いシス-2-ブテンを検 出したことから，シス型錯体として吸着していると推定 している。反応機構は, 図 22 のように考え, 気相の 1ブテンを通さず，シスートランス間の回転が， $\sigma$-錯体を 通して容易に起ることを強調している。<smiles>C=C(C)C=C[13CH2]</smiles>

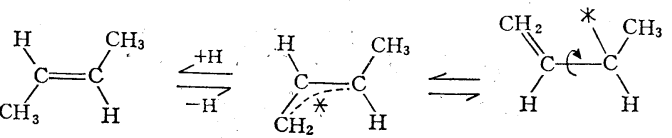

図 22 酸化亜鉛上のブテン異性化 ( $\pi$-アリル) 機構 (Kokes) なお，1ーブテンへはシス型 (アンチ型) またはトラン ス型（シン型） $\pi$ 錯体から Hを引きぬいて脱離すればよ い。ブテンに関しての直接証明にはならないが，現在ま

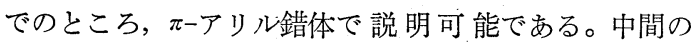
$\sigma$-錯体経由の速い転換については想像の域を出ない。

\section{VII. 金属水素化物によるブテン異性化反応}

金属水素化物の水素の触媒作用の研究は, Pease $5^{34)}$ がはじめ, Weller ら ${ }^{35}$ が炭化水素の水素の同位体 交換 をしらべる目的で, ブタンと水素化カルシウム, 水素化 バリウムの系を用いたことからさらに進んだ。彼らは, pri- $\mathrm{H}$ と sec- $\mathrm{H}$ の交換のしやすさに相異がないことか ら触媒上の水素は酸性ではなく, 触媒は金属的とみられ ることを指摘し，エチレン水素化，シクロヘキサン脱水 素など, 水素の関与する反応に, ニッケルや白金と同様 に有効であるとしている。

化学量論的な $\mathrm{CaH}_{2}$ や $\mathrm{BaH}_{2}$ および金属カルシウム, 金属バリウムなどには，水素化能も，異性化能もない。 水素化物を $200 \sim 300^{\circ} \mathrm{C}$ で高温脱気して $\mathrm{CaH}_{2-\mathrm{d}}, \mathrm{Ba}-$ $\mathrm{H}_{2-\mathrm{d}}$ のような非化学量論組成にしてはじめて触媒活性 を示すことがわかった。この水素化活性が， $\mathrm{CaO}$ によ るものでないことは水素处理により，より活性が増加す ること，また， $\mathrm{CaO}$ より活性が高いことから確認でき る。多羅間ら ${ }^{36}$ は, $\mathrm{CaH}_{2-\mathrm{d}}$ について, 脱水素量と表面積 の変化, エチレン水素化速度がともに $200 \sim 300^{\circ} \mathrm{C}$ の脱 気で急増することから，活性の高いのは $\mathrm{d}=0.3$ 位に相 当するものとしている。一方, 重水素を用いた実験か ら, $\mathrm{CaH}_{2-\mathrm{d}}$ のらち, 実際に $\mathrm{H}_{2}-\mathrm{D}_{2}$ 交換に関与してい る水素は, 約 $6 \%$ であり, 表面に露出している $\mathrm{Ca}$ につ き 1 個に相当することを明らかにした。ブテン異性化反 応をこの水素化カルシウム上で行うと，水素共存下の活 性は, $\mathrm{Pd}>\mathrm{CaH}_{2-\mathrm{d}}>\mathrm{Ta}>\mathrm{Ti}$ であり, 異性化は水素圧 には無関係であった。エチレン水素化を被毒するための $\mathrm{H}_{2} \mathrm{O}$ を $\theta=0.6$ 相当 (被覆率) 導入してもブテン異性 化はほとんど影響をうけず，したがって活性点として は，(i) 水素化，異性化ともに活性で，トランスへの選 択性が比較的大きいもの，(ii) 異性化のみに対して活性 で, 同じく選択性は比較的小さいもの，の二種類が存在 することがわかった。 $\mathrm{CaD}_{2-\mathrm{d}}$ を用いた異性化反応で， 高温になってはじめて生成ブテン中にDがみられること から, 触媒上の水素はかなり安定で, 水素を気相に存在 させない場合には, 水素脱離-付加の反応機構で進行し ているものと推定した。水素を共存させると，活性点 （ii）も有効となり，活性 およびトランスー2-ブテンへの 選択性がやや増大寸る。気相水素の生成ブテン中へのと り込みがみられることから，この場合には，水素がまず オレフィンに付加する付加-脱離機構で反応が進行する ものとしている。 $\mathrm{H}_{2}+\mathrm{D}_{2}$ の交換反応中には, 触媒自身 の水素はほとんど関与せず, 平衡化が起るが， $\mathrm{D}_{2}$ と 1ブテン共存の場合, 多量の HD が見出されていること から，1-ブテンからの解離水素と $\mathrm{D}_{2}$ からの解離水素で は，同椂の挙動をしているものとした。 
この他にも，水素化・脱水素に用いられる金属触媒上 でのオレフィン異性化，ここ 10 年余り急成長したゼオ ライト系触媒での多様性の期待される異性化反応, さら 飞酸化，脱水素などに重要な役割をはたしているスピネ ル，フェライト，その他の多くの複合酸化物上でのオレ フィンの挙動と異性化反応との関連, 固体酸触媒のひと つのモデル系でもあり，また新しい分野の触媒であるイ オン交換樹脂触媒，さらには配位子の選択性支配その他 の興味ある問題を含む遷移金属ートリフェニルホスフィ ン錯体，その他 $\mathrm{EDA}$ 錯体など，残された触媒系での問 題に限りはない。現象的な触媒物性, 触媒作用の探究か ら反応機構の詳細な研究に至るまで, オレフィン異性化 反応はひとつのテスト反応，あるいはモデル反応として 利用されてきたが，この役割は今後とも変らないであろ う。

以上, 最近目についた研究の中から, ブテン異性化反 応を中心に概括してみたものであるが，より複雑な異性 化の問題にまで立ち入らなかった。機会があればふれて みたいと思う。

\section{（昭和 47 年 5 月 1 日受理）}

\section{文献}

1) H.H. Voge, N.C. May, J. Am. Chem. Soc. 68550 (1949)

2) F. C. Whitmore, Chem. Eng. News 26668 (1948)

3) C.L. Thomas, Ind. Eng. Chem. 412564 (1949)

4) A.G. Oblad, J.U. Messenger, J.N. Brown, ibid. 391462 (1947)

5) J. Turkevich, R.K. Smith, J. Phys. Chem. 16 466 (1948)

6) P.J. Lucchesi, D.L. Baeder, J.P, Longwell, $J$. Am. Chem. Soc. 813235 (1959)

7 a) W.O. Haag, H. Pines, ibid. 822488 (1960)

b) W.O. Haag, H. Pines, ibid. 82387 (1960)

8 a) J. Wei, I and EC. (Fundamentals) 4161 (1968)

b) L. Riekert, J. Wei, ibid. 7125 (1968)

9) N.F. Foster, R.J. Cvetanovic, J. Am. Chem. Soc. 865416 (1964)

10 a) J.B. Peri, 2 nd Intern. Cong. on Catalysis. (Paris) 1960., Actes. Paris Edition Technip. 11333 (1961)

b) Proc. 3rd Intern. Cong. on Catalysis. (Amsterdam) 1-72 (1964)

11) L.H. Little "Infrared Spectra Inc. (London) of Adsorbed Species" Academic Press

12 a) H.P. Leftin and E. Hermana, Proc. $3 \mathrm{rd}$ Intern. Cong. on Catalysis. (Amsterdam) (1964) I-70 (1964)

b) H.P. Leftin. M.C. Hobson, Jr. Adv. in
Catalysis 14115 (1963)

13) D.M. Bronwer, J. Catalysis 122 (1962)

14a) H.R. Gerberich, W.K. Hall, Prep. Symp. on Chem. and Phys. Prop. of Catalysts (1965) B-173

b) W. Hightower, W.K. Hall, J. Am. Chem. Soc. 89778 (1967)

c) W. Hightower, W.K. Hall, J. Phys. Chem. 711014 (1967)

15) E.P. Parry, J. Catalysis 2371 (1963)

16) J.E. Mapes, R.P. Eishens, J. Phys. Chem. 58 1059 (1954)

17）上松敬禧, 千葉大学工学部報, 44155 (1971)

18a) M. Misono, Y. Yoneda, J. Catalysis 9133 (1967)

b) M. Misono, Y. Yoneda, J. Phem. 7644 (1972)

19）田中一範，第25回触媒討論会，触媒 11 199(1969)

20) K. Seyffarth, R. Letterer, H. Noller, 4 th Intern. Cong. No. 13 (Moscow) (1968)

21) Y. Kaneda, Y. Sakurai, S. Kondo, E. Hirota, T. Ohnishi, Y. Morino, K. Tamaru. 4 th Intern. Catalysis. (Moscow) No. 12 (1968)

22）御園生誠，谷敍孝，米田幸夫，第 5 回触媒研究発 表会 A-11 1971

23a) S. Bank, J. Am. Chem. Soc. 873245 (1965)

b) S. Bank, A. Schreisheim, C.A. Rowe Jr., ibid. 852115 (1963)

24）武純一郎，菊地宣二，米田幸夫，触媒 10127 (1968)

25）吉井直治，服部英，田部浩三，日化年会 29B 18 (1970)

26）小泉哲之，上松敬禧，橋本栄久, 日化年会 $252 \mathrm{~A}$ 21 (1972)

27) Y. Kubokawa, T. Adachi, T. Tomino, T. Ozawa, 4 th Intern. Cong. on Catalysls (Moscow) Pre p. 39 (1968)

28a) D.A. Dawden, D. Wells, 2 nd Intern. Cong. on Catalysis, (Paris). (1960). Actes. Paris Edition Technip, 1, 1499 (1961)

b) D.A. Dawden, "Catalysis Review" 51 (1971)

29）稲村清之, 小林徹, 根本洋二, 上松敬禧, 橋本栄 久，日化年会 2 A 22(1972)

30）佐藤誠, 川島一男, 上松敬禧, 橋本栄久, 46 年度 触媒研究発表会 A-13 1971

31）内藤周式，大西孝次，田丸謙二，日化年会 05507 (1969)

32) A.L. Dent, R.J. Kokes, J. Am. Chem. Soc. 926709 (1970)

33) A.L. Dent, R.J. Kokes, ibid. 75487 (1971)

34) R.N. Pease, L. Stewert, ibid. 42763 (1925)

35) L. Wright, S. Weller, ibid. 765302 (1954)

36）山口克, 平木洋三郎, 和田正大, 羅多間公雄, 45 年度触媒研究発表会 A-8 (1970)

37）金井宏俶，患憲治，46年度触媒研究発表会 B-31 